\title{
METHODS FOR PRETREATMENT OF LIGNOCELLULOSIC BIOMASSAND BY-PRODUCTS FOR LIGNOCELLULOLYTIC ENZYMES MODIFICATION: A REVIEW
}

\author{
MstNushrat Yiasmin ${ }^{1}$, AL-Ansi Waleed ${ }^{1,2}$, Xiao Hua $^{1 *}$ \\ ${ }^{1}$ School of Food Science and Technology, State Key Laboratory of Food Science and Technology, \\ Jiangnan University, 1800 Lihu Avenue, Wuxi 214122, China. \\ ${ }^{2}$ Department of Food Science and Technology, Faculty of Agriculture, \\ Sana'a University, Sana'a, Yemen. \\ *Corresponding Author: (X. Hua) huaxiao@jiangan.edu.cn \\ DOI: https://doi.org/10.51193/IJAER.2021.7108
}

\begin{abstract}
Because of its year-round availability as a sustainable source for industrial use, lignocellulosic content has gained considerable interest in the scientific community. Various industries reassess processes that integrate derived compounds from these materials as an alternative to the economic substratum. These varieties of fungi and bacteria are capable of depolymerizing degradant enzymes by lignocellulose biomass synthesis.Lignocellulolytic enzymes from fungi currently have a high variety of industrial applications due to the stability of catalytic activities and their high conversion rates. These products, in addition, deliver low energy inputs as economical, environmentally sustainable and non-toxic. For existing enzyme production technologies, techno-economic research suggests that synthetic production is not commercially viable. Rather, the economic forecasts for the use of the ligninolytic enzymes generated naturally are encouraging.
\end{abstract}

Keywords: Lignocellulosic by-products; Fungi; Lignocellulolytic enzymes; Catalytic activity.

\section{INTRODUCTION}

Lignocellulose is a highly degenerative polymer substance. Its structure consists mainly of a network of 1) cellulose (40-50 percent): formed by glucose monomers and the main component of plant cells that gives them strength; 2) hemicellulose (20-30 percent): a hexose, pentose and sugar acid polymer; and 3) lignin (10-25 percent): made up of three aromatic alcohols that form a protective shield around the other two polymers (Fig-1) (Sun et al., 2011), (Iqbal et al., 2011), (Durães Sette \& Costa Bonugli Santos, 2013), (Damm et al., 2016). Lignocellulose composition 
can vary depending on the source. Due to its design, however, lignocellulose saccharification is very difficult (Camacho-Morales et al., 2017). The conventional method for lignocellulosic waste degradation is acid hydrolysis and thermal shock, although it involves high energy cost procedures and unfavorable environment effects. In the case of acid hydrolysis, in particular, the most common method involves high acid concentrations and long retention periods. This not only means high costs, but also contributes to the production of toxic substances that can interfere with downstream fermentation. (V. K. Gupta et al., 2016), (Bak et al., 2009), (Damm et al., 2016), (P. Kumar et al., 2009). Intense energy costs, high costs and carbon pollution include physical processes such as mechanical extrusion and pyrolysis comminution; (Mohan et al., 2016), (P. Kumar et al., 2009).

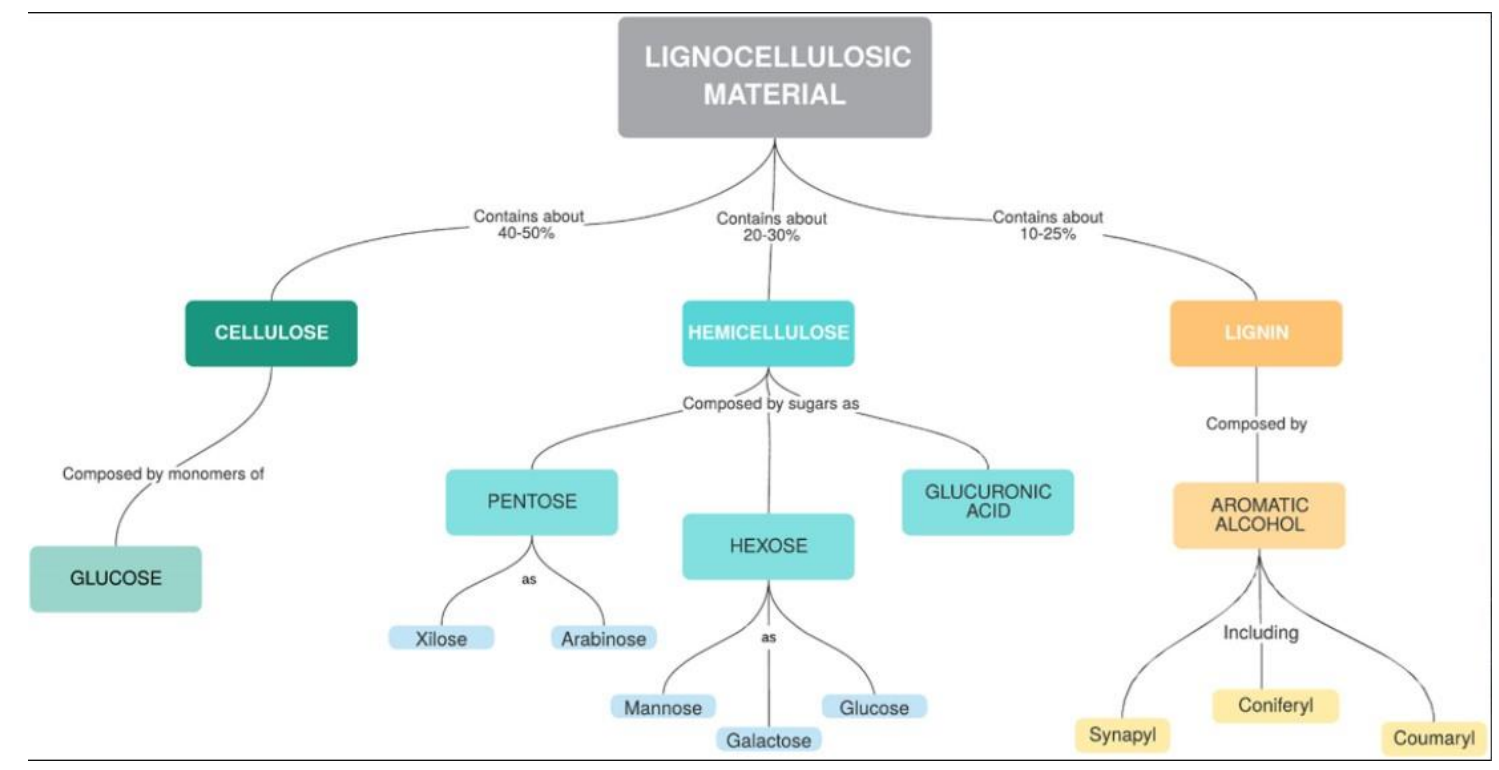

Fig. 1: Structural scheme of lignocellulosic material.

Cosy technology, high energy consumption is needed for physicochemical catalysis such as wet oxidation, carbon dioxide, plasma, and steam exploding. The conversion could also lead to the production of toxic substances, as most processes involve high pressure and temperatures. Pretreatment of biomass may produce enzyme inhibitory compounds.(Haghighi Mood et al., 2013).

An additional technology is being developed to increase the rates of biomass transformation, as are the ionic liquid (ILs) and the super-critical fluid. (Gu et al., 2013). The most famous fluid in this technology is supercritical $\mathrm{CO} 2 . \mathrm{CO} 2$ is cheap but demands high pressure and high temperatures which demand more energy and demand for manufacturing processes. (Gu et al., 2013). Biomass structure can be altered by disconnecting connections between cellulose, hemicellulose and lignin. The output for hemicellulose conversion is better than conventional 
biomass hydrolysis methods, reaching up to $99 \%$ in 4 hours at $160 \mathrm{oC}$ (Matsagar \& Dhepe, 2017). The requires a significant amount of ILs are that with few exceptions they are costly (e.g. cholinium). Although many ILs are non-biodegradable and unsafe for proteolytic enzymes, plants and animals. (Frade \& Afonso, 2010), (Shirkavand et al., 2016). In addition, ILs are heavier than water and become more viscous throughout the process, resulting in difficulties using them. (Haghighi Mood et al., 2013), (Asim et al., 2019).

On the other hand, enzymatic hydrolysis may be advantageous for the degradation of lignocellulose, allowing polymers with low energy consumption and high specificity to be effectively broken down without the creation of toxic by-products. (Fig-2) (Table-1) (V. K. Gupta et al., 2016), (Haghighi Mood et al., 2013), (Singh et al., 2016). The technology has shown the efficacy of lignocellulosic by-product hydrolyses with enzyme systems; some drawbacks still exist today, and they must be overcome if their use is to be extended. Firstly, the digestion time must be decreased so that hydrolysis conditions can be optimized. The second is that in few companies that sell the industrial enzymes, so the cost of the enzymes is very high as the low supply chain (Singh et al., 2016). This application of enzyme hydrolysis with other physical, chemical or physicochemical pretreatment methods has shown that the time taken for the conversion of biomass has been reduced and more cost-effective. However, further studies in combined processes are required to explore environmental effects and energy balance (Shirkavand et al., 2016).

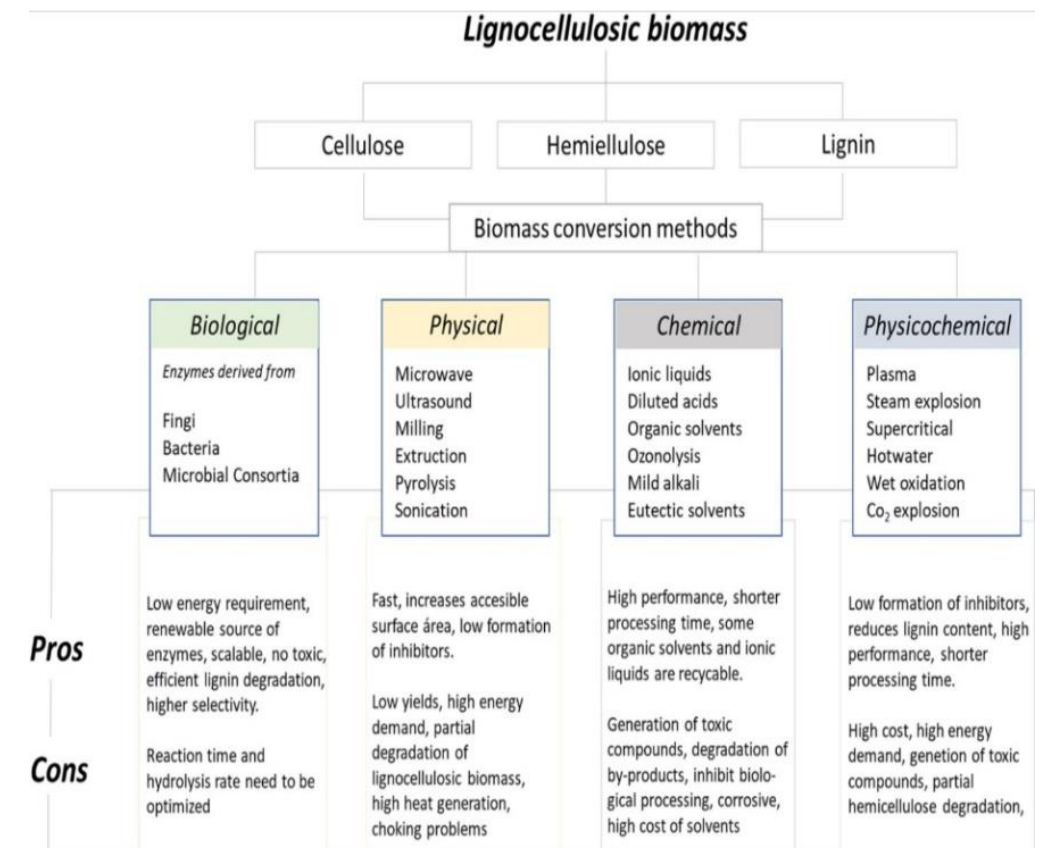

Fig. 2: Comparison between different biomass conversion methods 
Table 1: Advantages and drawbacks of enzyme-catalyzed biomassconversion.

\section{Enzymatic hydrolysis}

\begin{tabular}{|c|c|c|}
\hline Advantages & Drawbacks & Reference \\
\hline $\begin{array}{l}\text { Effective in degradation of lignin and } \\
\text { hemicellulose at normal temperature. }\end{array}$ & Low rate of hydrolysis & $\begin{array}{l}\text { (Bhatt \& Shilpa, } \\
\text { 2014) }\end{array}$ \\
\hline
\end{tabular}

Low energy consumption.

Environmentally friendly.

Organisms will degrade lignin.

Low energy requirement.

Mild reaction conditions.

High selectivity toward desired product

Whole cell (e.g. fungi or bacteria) biocatalytic processes are scalable

No inhibitors generation

No chemical or harsh conditions required

Low energy requirements

Carry out at mild conditions at $40-50^{\circ} \mathrm{C}$

High yields of sugars can be obtained

No inhibitors formation

Low energy requirements

Delignification

Reduction in degree of

polymerization of cellulose

Partial hydrolysis of hemicelluloses

No chemical requirements
Long reaction time 2 to 4 weeks

(Ussiri \& Lal, 2014)

Narrow operating conditions.

High volume of waste water.

(Chatterjee et al., 2015)

High volume of waste water produced during product purification

very low rate at experimental stage

(Saini et al., 2015)

High cost of catalysis.

(Jahnavi et al.,

Takes longer than other methods.

2017)

Product inhibition during hydrolysis

Slow process rate

(Ingle et al.,

Very low treatment rate

2019)

Not very effective for commercial application 
Mild environmental conditions

No protection/deprotection steps involvement

(Parra-Saldivar

Economical

et al., 2020)

Environmentally friendly

Display regioselectivity, diastereoselectivity, enantioselectivity, and chemoselectivity

Most of those fungi and bacteria have formed in a synergistic system through the development of lignocellulolytic enzymes which have the capacity to break down key LCB polymer. (2) cellulolytic enzymes like endoglucanase, exoglucanase, and B-glucoside, and (3) hemicellulolytic enzymes like endoxylase, arabinofuranosidase, $\beta$-xylosidases and feruloyla esterase, and other cellulolytic enzymes able to deteriorate lignocellulotic biomass in the system of a synergistic system these enzymes are: (1) the laccae enzyme, lignin peroxidase and polymorphosa (Fig-3) (Jayasekara \& Ratnayake, 2019). These groups are called lignocellulolytic enzymes that can degrave the main polymers of lignocellulosic materials.

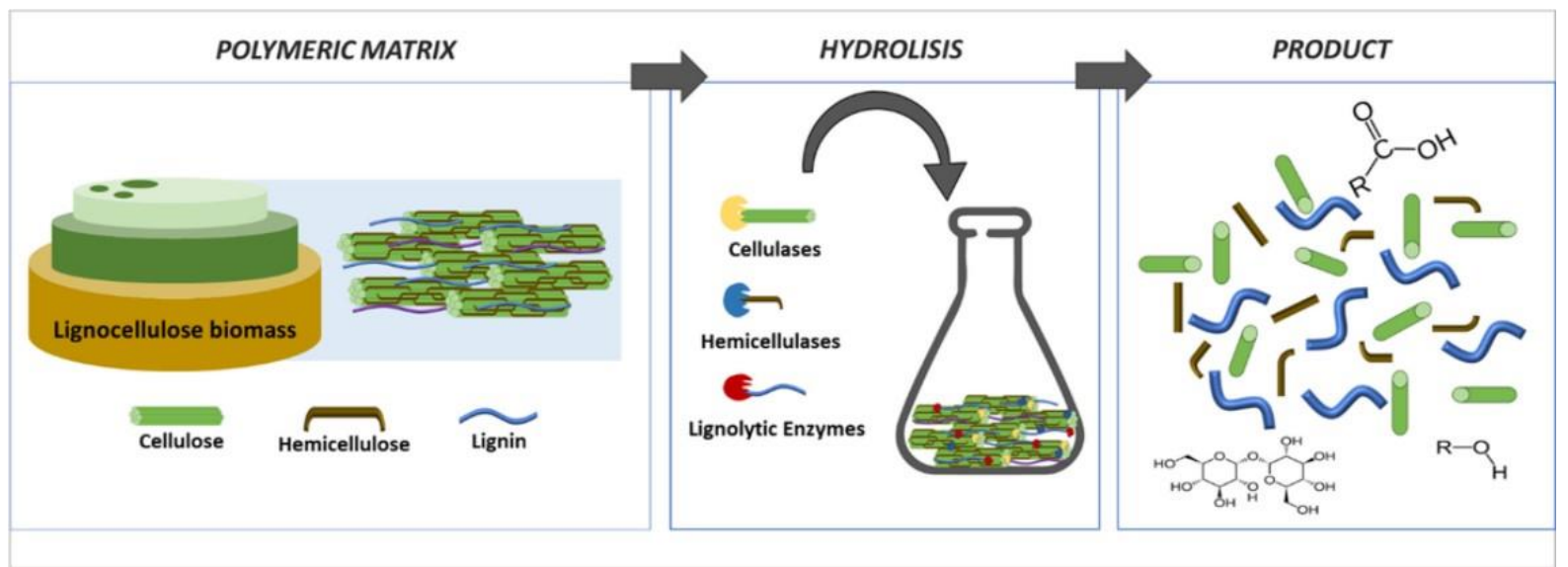

Fig. 3: Enzymatic hydrolysis of lignocellulosic material.

Interestingly, the lignine, including cellulose, can be degraded effectively by a number of selected groups of fungi such as white-red fungi, Phanerochaete chrysosporium, Ganoderma lucidum, Pleurotus dryinus, Pleurotus ostreatus, Tramethe versicolor and Trametes hirsuta (Anwar et al., 2014), (Mattila et al., 2017), (Millati et al., 2011), (Karimi \& Zamani, 2013),( Manavalan et al., 2015). Filamentous fungi such as Aspergillus niger, Trichoderma viride and Penicillium nonetheless effectively decumb, but lignin can only partially degrade(Anwar et al., 2014), (Asgher et al., 2013).

There are currently several industrial applications using a variety of lignocellulolytic enzymes extracted from fungi. One of the best applications was the enzyme hydrolysis in the second 
International Journal of Agriculture and Environmental Research

ISSN: 2455-6939

Volume: 07, Issue: 01 "January-February 2021"

generation bioethanol production systems. (Anwar et al., 2014), (P. Kumar et al., 2009), (Asgher et al., 2013). Other applications of notorious importance are also: 1) Development of the feed supplement to improve the digestibility of nutrients. 2) Paper as a sustainable pulp blanching alternative. 3) Flavor and aromatic characteristics of the wine/fruit juice food industry. 3) 4) Manipulation of bread dough texture. 5) Take out recycled paper ink. 6) Textile dyes for bleaching. 7) Biorestructuring of the soil. 8) Synthetic chemical oxidative deprotection (Khambhaty et al., 2018), (He et al., 2010), (Jordan \& Wagschal, 2010) And further explained other more applications.

At economic level there is a great potential for producing enzymes involving the deterioration of lignocellulosic by-products, adding value to waste materials, thus reducing the environmental impact of waste materials. (Singh et al., 2016). Lignocelulosis biomass degradation systems, lignocellulolytic enzymes derived from fungi are discussed, their projected demand, challenges and emerging trends for industrial and commercial use of lignocellulolytic enzymes are discussed.

\section{LIGNOCELLLOLYTIC ENZYME STATISTICS AND MARKET VALUE}

Due to its broad industrial uses (e.g., chemicals development and degradation of recalcitrant contaminants, medicines, biofuels, textiles, foods and drinks), and others, the lignocellulolytic enzyme demand has increased over recent years(Frazer, 1999). It makes them key enzymes for developing and developed countries' economic growth because of their effect on industrial processes relating to goods and services development. (Jayasekara \& Ratnayake, 2019). The demand for industrial enzymes could increase from $\$ 5.5$ billion in 2018 up to $\$ 7.0$ billion by 2023 at a compound annual rate of growth (CAGR) of 4.9\% (2018-2023) as stated by Business Communication Company (BCC) Study. (Dsm, 2019). Enzymes in the textile, leather, paper and bio-diesel industries are increasingly produced, especially enzymes. This leads to the approach of immobilized biocatalyst scaling processes (Chapman et al., 2018).

All of the industrial enzymes requested are primarily divided into three categories: manufacturing, agriculture, and the environment, with an annual growth rate of up to 8\%. (Fig5). Largely condensed in several developed countries, including the U.S., Germany, the Netherlands, Denmark and Suiza, North America represents the bigest market for industrial enzymes in the world (40 per cent), led by Europe (30 per cent), (Nunes, 2018),(Jaramillo et al., n.d.). Developing Asia-Pacific countries are expected to broaden their markets in order to meet nutrition demand. Brazil, a Latin American country, is a leader in bioethanol production and consumption worldwide. The increased interest in lignocellulolytic enzymes is related to their use of lignocellulosic content for the development of second-generation agroethanol. (Nunes, 2018), (Sarrouh, 2012). 
Against this backdrop, there will obviously continue to expand the industrial enzyme market, as biotechnology developments in development are currently very small. Thus, research should aim at discovering new sources in this sector such as fungal derived enzymes, cost-effective alternatives for scaling up production and optimizing the general conditions to meet the global demand for lignocellulosus products and services.

\section{ENZYMESDEGRADATION OFLIGNOCELLULOSE}

Lignocellulose is the world's most abundant polymer; lignocellulose content contains nearly half of the biomass. (Toushik et al., 2017). As major substrate, cellulose, hemicellulose and lignin polymers are found in lignocellulose degrading enzymes. These enzymes are important if they are used by various species for the development of many other added value chemical products and metabolites. very complex matrices in available sugars. (Abdel-Hamid et al., 2013). The classification of lignocellulolytic enzymes in general is described Fig-4
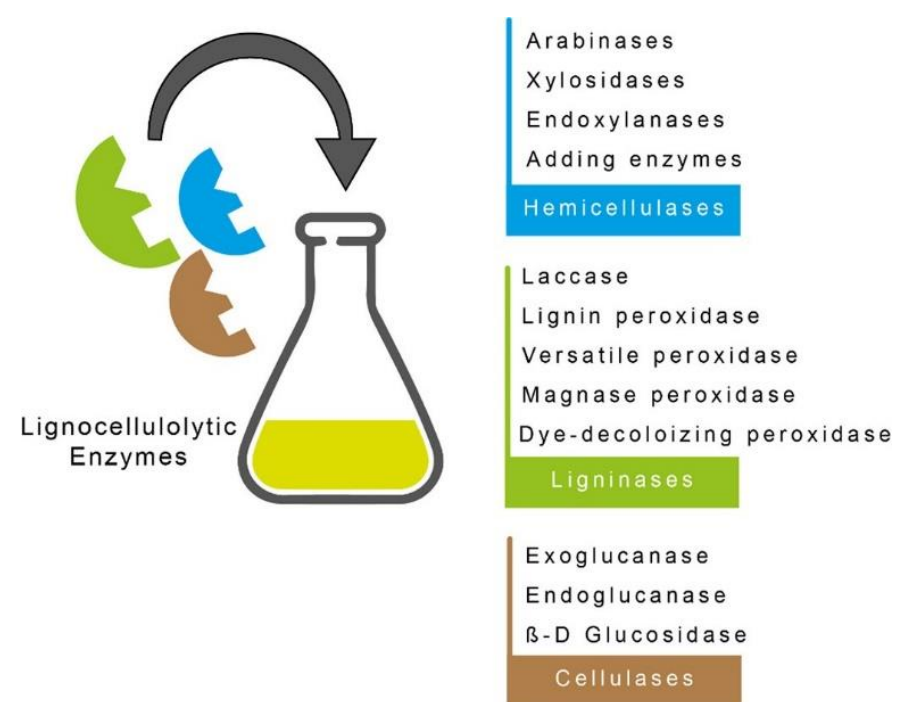

Fig. 4: Classification of lignocellulolytic enzymes

\subsection{The Cellulose}

Cellulose has been one of the world's most abundant organic polymers, provided mainly by plants (Srivastava et al., 2021). Cellulose applications are widely recognized among the most important industries that use it, including paper and pulp, textiles, detergents, food, animal industries, chemicals, fuel and pharmaceutical goods. (Srivastava et al., 2021), (Arrieta et al., 2016), (Molina et al., 2016). It is also the most abundant and essential structural components of 
the plant's primary cell wall, which is made up of many units of D-glucose connected by the glycosidic relations. (Garcia-Maraver et al., 2013), (Hosseini \& Shah, 2011), (Jia et al., 2020).

Due to the strong hydrogen bonds and cyclic structure of the main polymer chain, the rigid cellulose structure (Poletto et al., 2014). There are, therefore, a high melting point and glass transition temperature for cellulose and some derived components. (Zhao et al., 2016). Additionally, the intramolecular hydrogen bonds between the hydroxyl groups are a function of an insoluble amount of cellulose. Such bonding produces an ordered crystalline zone blocks access to several organic solvents and water, so a strong alkaline such as caustic soda is important for breaking the main structure and making hydroxy groups accessible to reactive. (Garcia-Maraver et al., 2013).

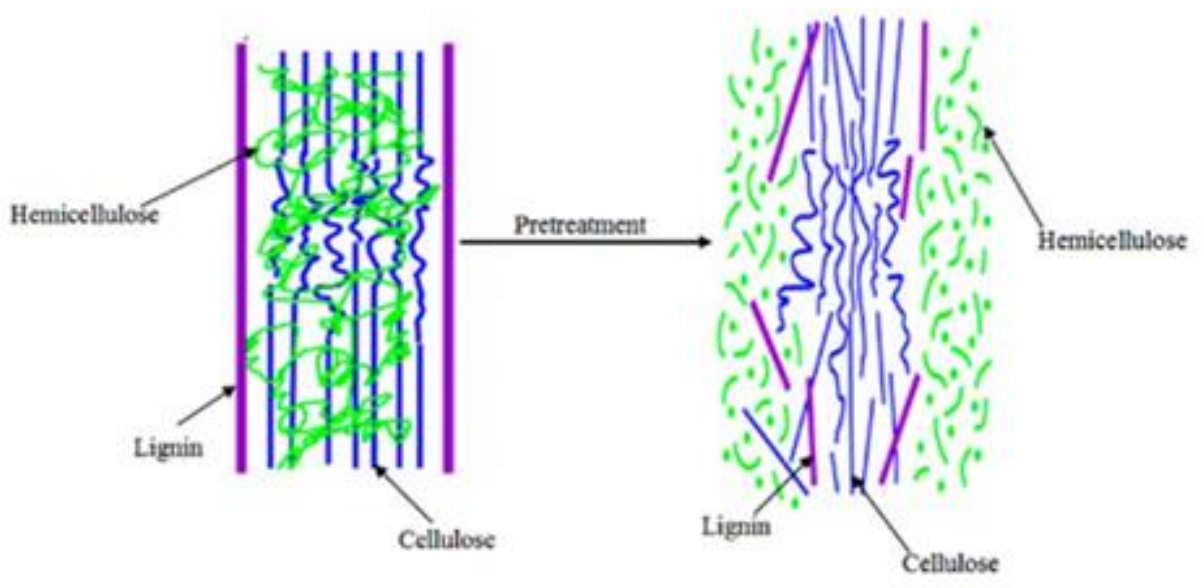

Fig. 5: Schematic of the role of pretreatment in the conversion of biomass to fuel. (Adapted from (P. Kumar et al., 2009)

Cellulases are a series, carried out by two stages of Hydrolysis, of enzymes responsible for the bioconversion of cellulose to soluble sugars and glucose. Endoglucanases and exoglucanases degrade the substratum in the first stage and release the complex organized sugars to the liquid process with a polymerization process of up to six degrees (Jayasekara \& Ratnayake, 2019). $\beta$ glucosidase converts cellobioses into glucose in the second stage (Toor et al., 2020). Some microorganisms, such as bacteria, fungi and actinomycets, can generate three types of cellulasecontaining components: exo-1,4- $\beta$-D-glucanase; endo-1,4- $\beta$-D-glucanase;(Horn et al., 2012)(M. Zhang et al., 2020), (Yao et al., 2016)In addition, fungi are known to create monooxygenasses of lytic polysaccharides, degrading cellulose of cellobiosis. The following are listed in greater detail in these five components. 
International Journal of Agriculture and Environmental Research

ISSN: 2455-6939

Volume: 07, Issue: 01 "January-February 2021"

\subsubsection{Exoglucanase}

Exo-1,4- $\beta$-D-glucanases include the 1,4- $\beta$-D-glucan glucohydrolases (EC. 3.2.1.74) which help release D-glucose from 1,4- $\beta$-glucans and then hydrolyze D-cellobiose progressively and 1,4- $\beta$ D-glucan cellobiohydrolase (EC. 3.2.1.74), which is in charge of detaching D-cellubiose from $1,4-\beta$-glucans (Zhao et al., 2016). As processive enzymes, exo $(1,4) \beta$-D-glucanases can separate from the cellulose polymer by the reducing or non-reducing end, and then start producing units of cellobiose (Langston et al., 2011) or glucose as major products (Brum et al., 2012). Like other cellulolytic enzymes, exoglucanases are widely used in the industry, as it will be detailed further on in this review.

\subsubsection{Endoglucanase}

Also known as 1,4- $\beta$-D-glucan-4-glucanohydrolase (EC 3.2.1.4) is endoglucanases. They are randomly cut in internal amorphous positions, which are $\beta(1,4)$ glycosidic bonds, into oligosaccharides by cellulosic chains (Molina et al., 2016). These enzymes are present in many species, most commonly bacteria (anaerobic and aerobic), thermophilic and mesophilic microbes and fungi, but are also widespread in nematodes, protozoans, insects and molluscs which are complex to degrade cellulolytic materials in enzymatic batteries (Jordan \& Wagschal, 2010), (Shah et al., 2019). Fungi are the most commonly used species for the development of lignocellulolytic enzymes at commercial levels (e.g., Trichoderma, Phanerochaete, Aspergillus, Trametes, Penicillium) (Karim et al., 2015). Endoglucanases have potential uses in the textile, paper and food industries (Brum et al., 2012).

\subsection{3. $\beta$-D Glucosidase}

The final stage of cellulose hydrolysis is induced by these enzymes (EC 3.2.1.21). They release cellulodextrin and cellobiosis from soluble D-glucose units (Yao et al., 2016). $\beta$-D Glucosidases are crucial for the cellulase degradation system, since they induce the cellulase enzyme system by synthesizing gentiobiose and sophorose (Naraian \& Gautam, 2017). $\beta$-glucosidases are typically formed in an extracellular or intracellular manner by mammals, plants, fungi and bacteria. This enzyme has a high trade potential, as it has a broad range of applications in various industries such as textiles, animal feed, esthetics, natural polymers, organic chemicals, etc (Naraian \& Gautam, 2017).

\subsubsection{Lytic polysaccharide monooxygenases}

These copper enzymes are connected to crystalline cellulose degradation (Karim et al., 2015). In order to activate the molecular oxygen at their copper active position, LPMO (EC 1.14.99.54) requires a reduction substrate (Frommhagen et al., 2017). Artificial reducers like ascorbic or 
gallic acid are usually employed for reducing $\mathrm{Cu} 2+$ to $\mathrm{Cu}+$. The $\mathrm{Cu}+$ ion is then reacted to a reactive copper-superoxide complex by converting $\mathrm{O} 2$. The monooxygenase activity and the oxidation of crystalline polysaccharide chains are accomplished by this reaction. In synergistic actions with CDH LPMO can work because these enzymes can also supply electrons as the reductants (Karim et al., 2015), (Frommhagen et al., 2017).

\subsubsection{Cellobiose dehydrogenases}

CDH produces white red fungi (EC 1.1.99.18). These extracellular enzymes have distinct domains of flavin and heme. (Karim et al., 2015), (Sulej et al., 2019). After the flavin domination is intra molecular electron transferred, the heme domination is able to transfer electrons from cellulose products to LPMO (Karim et al., 2015). CDH generates lactone and releases a reduced accepter using a cellobiosis and an acceptor like FAD, in this case a FADH2 (Sulej et al., 2019). CDH is also a catalytic LPMO electron donor. (Laurent et al., 2019).

\subsection{Hemicellulose}

In strengthening the cell walls of the plants Hemicellulose plays an important role by forming a system of hydrogen bonds that provide high stability and rigidity in cell walls, along with cellulose fibers and lignin residues. (Guerriero et al., 2016), (Ibn Yaich et al., 2017), (Kim et al., 2017). Hemicellulose is the second most common component of lignocellulose. (Jayasekara \& Ratnayake, 2019). It contains most of pentose, as xyloosis and arabinose and is a complex and heterogeneous polymer. The pentose forms a $\beta$-(1 to 4$)$ connection that conforms to the linear structure of the backbone, where its side groups are substituted in the majority of cases with hexosis such as galactose, glucose, manneses, and sugar acids. (X. Zhang et al., 2011). The variation in the composition of Hemicellulose is determined by plant species, type of tissue and stage of growth. Hemicellulose is primarily composed of xylans in angiosperms (monocots and dicots), while glucomannans, in addition to xylans, are main components of gymnosperms. (Eronen et al., 2011), (Tenhunen et al., 2014), (Naidu et al., 2018), (Penttilä et al., 2013). Because of their broad concentration in the base structure, hemicellulose in cereals is often referred to as arabinoxylans. On the other side, hardwoods have a high D-glucuronic acid concentration which is called glucuronoxylan. The other two classifications are homoxylene, where the xylose units are bound to $\beta-1,4$ bonds by the composition of the main chain of the hemicellulose structure, and glucuronoarabinoxylene which alternates between xylose, Dglucuronic acid and L-arabinosis monomers by its main chain (Polizeli et al., 2005), (Sun et al., 2011). It is a short strand arrangement of 100 to 200 residues, with ramifications which cause instability and make hydrolyzing much easier compared to homogeneous cellulose structures. 
International Journal of Agriculture and Environmental Research

ISSN: 2455-6939

Volume: 07, Issue: 01 "January-February 2021"

However, some recurrent oligomeric structures, complex branching and acetylation are affecting depolymerization (Kameshwar \& Qin, 2017).

It is a short strand arrangement of 100 to 200 residues, with ramifications which cause instability and make hydrolyzing much easier compared to homogeneous cellulose structures. However, some recurrent oligomeric structures, complex branching and acetylation are affecting depolymerization (Broeker et al., 2018). Without enzymes attacking its many implications, a complete xylanolytic system would not be like that. Xylanases are identified by genetic data and structural analysis (Bennett, 2003), (Motta et al., 2015).

\subsubsection{Endoxylanases}

Without enzymes attacking its many implications, a complete xylanolytic system would not be like that. Xylanases are identified by genetic data and structural analysis (EC 3.2.1.32). The same form of bond breaks down with carbon 1 and 3, resulting in xylobiosis, xylotriosis and xylotetraose formation. The non-reducing residue of the alpha-D-xylose terminal is hydrolysed and released from alpha-d-xylose (EC 3,2.1.177) (Luo et al., 2016), (Carli et al., 2016). As an animal feed supplement, endoxylanases were marketed. Endo-1,4-beta-xylanase (EC 3.2.1.8) is used to enhance digestibility of nutrients in weaned pork (He et al., 2010). Modification of textures, resistance to dough and crumb structures, and the application of these enzymes in the food industry may be manipulated. (Dornez et al., 2007), (McPhillips et al., 2014), (Wang et al., 2018). Some other test for endo-1,4-beta-xylanase is a sustainable alternative to pulp bleaching in the paper industry (Khambhaty et al., 2018) and the elimination of excess photocopying material (Pathak et al., 2014).

\subsubsection{Arabinofuranosidase}

In the GH43 band, the arabinose side-chains of the backbone of xylose residues include an $\alpha$-Larabinofuranosidases (EC 3.2.1.55) and endo- $\alpha$-L-arabinanases (EC 3.2.1.19). These behaviors are unique to any organism that degrades the cell wall. The glycosidic bond between Larabinofuranosides is broken by the enzymes of the GH51 family. One illustration is that alpa-Larabinofuranosidase is not reduced at the end. (Gilbert et al., 2008) removing the side chains of Arabinose by hydrolyzing the bond between Arabinofuranose at the non-shrinking terminology of Arabian (Dornez et al., 2007),(McPhillips et al., 2014),(Wang et al., 2018). The potential food sweetener and inhibition of sucrose digestion characteristics of alpha-L-arabinofuranosidase have been assessed. Another use in the food field of aromatic and flavor-related properties in wine and fruit juices and manipulation of bread dough texture. Pumps in the paper industry and the manufacture of bioethanol are other industrial applications of alpha L-arabinofuranosideas to enhance digestion and the processing of pulp. (Broeker et al., 2018), (Gilbert et al., 2008). 
International Journal of Agriculture and Environmental Research

ISSN: 2455-6939

Volume: 07, Issue: 01 "January-February 2021"

\subsection{3. $\beta$-D-Xylosidases}

The GH43 family is made up of $\beta$-D-Xylosidases. Xylan-1, 4- $\beta$-xylosidase (EC 3.2.1.37) removes residue of xylan from ends that do not have xylooligosaccharide reduction agents(Juturu $\& \mathrm{Wu}, 2012)$, (Ghosh et al., 2019). Also capable of hydrolyzing xylobiosis is the development of monosaccharide xylose. $\beta$ - D-xylopyranosidase extracts glycosyl residues from their substratum's non-reducing ends, according to CAZy. according to the GH3 family. In different industries, Xylan-1,4- $\beta$-xylosidase (EEC 3.2.1.37) plays a role in extracting ink from recycled paper, processing wood pulp, bread dough consistency and wine-producing aroma release (Jordan \& Wagschal, 2010), (Gu et al., 2013).

\subsubsection{Esterases}

Acetyl-xyl esterase releases o-acetyl groups into acetyl-xylans with hydrolyzing acetyl ester bonds (Penttilä et al., 2013), (Motta et al., 2015). The enzyme (EC 3.1.1.72) Catalyzes the polymer xylon, xylatedacetylon, glucose acetylon, $\alpha$-Napthyl acetate and p-nitrophenyl acetate hypersensitive and without effects on mannan or pectin acetylated. Catalyzes Feruloyl esterase (EC 3.1.1.73) is hydrolyzing feruloyl ester bonds to xylanes to remove ferulic acid from arabinoses.(Penttilä et al., 2013), (Motta et al., 2015). Esterases are also called accessory enzymes for hemicellulase as they hydrolyze hemicellulose from pectinases and xylanases. For the paper blanching procedures of the sulfite pulp, acetyl-xylan esterase (EC 3.1.1.72) was utilized. This enzyme has been identified as a potential medicine agent in hydrogel development by the pharmaceutical industry (Adesioye et al., 2016).

\subsubsection{Aiding enzymes}

Licheninase (EC 3.2.1.73) works on ( $1 \mathrm{x}>4)$-beta-D-glycoside links in beta-D glycoside bonds $(1 \times 3)$ and $(1 \times 4) /$ ligaments. Unique to xyloglucano oligosaccharides, Xyloglucano-specific endo-beta-1,4-glucanase (3.2.1.15) has an effect not on other cell wall components yet. Xylose bonds with a xylooligosaccharide release exo-(1.5) Xilanase $\beta-1.4$ Xylose bonds xylooligosacchariids (EC 3.2.1.156) (Penttilä et al., 2013), (Motta et al., 2015). Alphaglucuronidase (EC 3.2.1.139) (Gilbert et al., 2008) enables the hydrolyzing of alpha 1,2glycosidic glucuronoxylan ties to eliminate side chains of glucuronic acid. (CAZy; $\sim$ www.cazy.org/). Because of its thermostable properties, licheninase has a possible use in the beer industry and feed industry. (Niu et al., 2016). As for alpha-glucuronidase (EC 3.2.1.139), bioethanol processing and wood pulp bleaching are industrial applications(Adebami \& AdebayoTayo, 2020).

\subsection{Lignin}


International Journal of Agriculture and Environmental Research

ISSN: 2455-6939

Volume: 07, Issue: 01 "January-February 2021"

In all lignocelluloses, lignin is a complex biopolymer. It is formed during photosynthesis and often has a link in cell walls with cellulose. It has no "defined" structure because of its complexity and can differ from type to type of plant. There are 3 major monomers of p-coumaryl alcohol, coniferyl alcohol and sinapyl alcohol. Polymerization once, The p-hydoxyphenyl units, guaiacyl unit, and syringeyl unit form three correspondence phenylpropanoic monomeric units (Davis et al., 2016), (Marcelo et al., 2013). They are all comprised of a phenolic community that constitutes the main substratum for enzyme deterioration.

Lignin is resistant to degradation because of its hetepolymeric, amorphous and complex composition. (Suárez Arango \& Nieto, 2013), (M. Li et al., 2016). There are a variety of ways to depolymerize. The enzyme method is the course of white-red fungi. Because of lignin variation and size, enzyme systems are not unique and occur outside the cell (extracellular). (Asier et al., 2010). While this is a process involving a variety of enzymes, five are most effective: DYPs, flexible Peroxidase (VP), Manganese Peroxidase (MnP), Lignin Peroxidase (LiPs), and laccase. Therefore, there are five enzymes in the body: (Lacc) (Abdel-Hamid et al., 2013), (CamachoMorales et al., 2017). This enzyme output is equalized with the production and degradation of lignin, which is why it is known as non-specific. For example, in Nitrogen-regulated organisms, $\mathrm{LiP}$ and $\mathrm{MnP}$ are regulated by nitrogen restriction (Manavalan et al., 2015), (Camacho-Morales et al., 2017). The following are further explained: priority enzymes, aryl-alcohol oxidases, glyoxidae, unspecific peroxygenases, aryl-alcohol dehydrogenases, and quinone reductases.

\subsubsection{Dye-decolorizing peroxidases}

DyPs will decarboxylate non-phenolic substrates associated with lignin as their key product panisaldehyde(Abdel-Hamid et al., 2013). You have a prothetichema group and you have a fold like ferredoxin(Camacho-Morales et al., 2017). By using phezolic lignin dimers, this enzyme indicates its potential for oxidase. A large range of DyP products include Vanillin, Guaiacol, Cresol and many other by-products(Abdel-Hamid et al., 2013). These enzymes, as the name implies, are used for decoloration and treatment of wastewater because they are used to dissolve high redox anthaquinone dyes, $\beta$-carotenes, aromatic sulfides, azo dyes and manganese. (Santos et al., 2014).

\subsubsection{Versatile peroxidase}

Via different oxidative sites and hemes, these enzymes (EC 1.11-1.16) are known (Abdel-Hamid et al., 2013). The catalytic activities of $\mathrm{MnP}$ and $\mathrm{LiP}$ can be performed with several peroxidases that can oxidize Mn2+ and high redox potential NPCs (Abdel-Hamid et al., 2013). Its catalytic diversity makes it possible to apply it in reactions mediated or independent of $\mathrm{Mn} 3+$ or $\mathrm{Mn}$, resulting in convenient use of high and low redox potential aromatic substrates for such reactions 
International Journal of Agriculture and Environmental Research

ISSN: 2455-6939

Volume: 07, Issue: 01 "January-February 2021"

(Abdel-Hamid et al., 2013). It is also considered a "hybrid" enzyme, called MnP-LiP (Camarero et al., 1999). VPs are used for decoloration of industrial dyes, toxins, industrial biocatalysts and bioremediation in textile industries (Camacho-Morales et al., 2017), (Tinoco et al., 2007), (Asgher et al., 2008), (Karigar \& Rao, 2011).

\subsubsection{Manganese peroxidase}

The major distribution companies in $\mathrm{MnP}$ are fungi from white to red (EC 1.11.1.13). This glycosylated hemoprotein uses $\mathrm{Mn} 2+$ to bind $\mathrm{Mn}+3$ ions to dicarboxy and alpha-hydroxy acids as oxidizing substrate.(Camacho-Morales et al., 2017). Almost every wood-colonizing fungus secretes these enzymes and is seen as the most frequent peroxidase for lignin transition. (Camacho-Morales et al., 2017). Phenolic substrates have an affinity, but MnP can also function on non-phenolic compounds(Asier et al., 2010). For processes such as bioblasting, pulping and purification of bleiching plant effluent pulp and paper industries, these enzymes are used (Winquist et al., 2008). Often used in the dairy, clothing, pharmaceutical and bioremediation industries are MnP enzymes. (Karigar \& Rao, 2011).

\subsubsection{Lignin-peroxidase}

The phenol and non-phenolic substrate can be oxidized as a result of this enzyme (EC.1.11.1.14). LiP enzymes have distinctive redox ability, are also glycosylated hemoproteins and are highly dependent upon concentrations of hydrogen peroxide (Camacho-Morales et al., 2017). Although $\mathrm{LiP}$ is generally considered the primary catalyst in oxidative lignin depolymerisation, some white-red fungal substances do not generate these enzymes, laccases are therefore the solution. (Abdel-Hamid et al., 2013), (Eggert et al., 1996). LiP enzymes are applied in the fruit, paper and pulp, fiber, drug and bio-remedial industries (Karigar \& Rao, 2011).

\subsubsection{Laccases}

The names of the largest blue multicopper oxidases (EC 1.10.3.2) are in Laccases. The copper redox power is used to catalyze a variety of aromatic substrates via an oxidation reaction (Tovar Herrera, 2013). Within the substrates which these enzymes can use are aromatic compounds, metal ions (such as $\mathrm{Mn}^{2+}$ ) and organometallics(Abdel-Hamid et al., 2013). The catalysis resulting from laccases can be used with mediators on non-phenolic substrates. These mediators have a low molecular weight and an enzyme is oxidized. They are extremely active cation radicals that improve oxidation. (Mate \& Alcalde, 2017). The most efficient mediators, such as hydroxybenzotriazole (HBT), are the N-heterocycles with $\mathrm{N}-\mathrm{OH}$ ring, while 2,2'-azino-bis (3ethylbenozthiazoline-6-sulfonic acid) is also a common alternative. (Abdel-Hamid et al., 2013). Laccases are multi-use enzymes and different enzymes are further described. 
International Journal of Agriculture and Environmental Research

ISSN: 2455-6939

Volume: 07, Issue: 01 "January-February 2021"

\subsubsection{Aryl-alcohol oxidases}

In addition, lignin degradation for many white-rot basidiomycetes is involved in fungal arylalcohol oxidases (EC 1.1.3.7). This flavoenzyme is secreted by said species. Alcohols are mostly oxidized by AAO, both aromatically and predominantly, but in compounds such as furans and aldehyde groups with lower catalytic effectiveness, they can directly oxidize carbonyl groups. (Ferreira et al., 2009),(Carro et al., 2015). AAO reduces $\mathrm{O} 2$ to generate $\mathrm{H} 2 \mathrm{O} 2$. This reduces $\mathrm{O} 2$. Two electros from alcohol substrates are extracted for that purpose and transferred to other oxidising substrates via the reduced AAO flavin to 02 forming $\mathrm{H} 2 \mathrm{O} 2$ or $\mathrm{O} 2$. Substrate in lignin degradation, such as UPO, is then used by hydrogen peroxides as(Carro et al., 2015).

\subsubsection{Glyoxal oxidase}

The degradation is due to the copper-containing oxidoreductases, such as laccasses. Glyoxal oxidases are included (EC 1.2.3.15). Like AAO, they develop white red fungi with $\mathrm{H}_{2} \mathrm{O}_{2}$. (A. T. Martínez et al., 2017). GLOX enzymes are known to be present in wood-degrading molds, particularly in white-red degradation and symbiotic fungus as an extracellular enzyme. Fungal GLOX are activated in vitro by peroxidases, which seems to suggest that these enzymes have a synergistic and regulatory relationship. Methylglyoxal and glyoxal are the primary GLOX substracts, but lignin degradation products may also be treated. (Daou \& Faulds, 2017).

\subsubsection{Unspecific peroxygenases}

These enzymes are co-substrate dependent on the existence of $\mathrm{H} 2 \mathrm{O} 2$. For this reason, they are called "self-sufficient" (A. T. Martínez et al., 2017). UPO (EC 1.11.2.1) supports a wide variety of catalytic reactions such as hydroxy, epoxidation, O- and N-dealkylation, aromatization, sulfoxidation, $\mathrm{N}$ oxygenation, dichlorination, halide oxidation. (Carro et al., 2015), (Karich et al., 2017), (Hofrichter et al., 2015). UPO is using hydrogen peroxide to create alcohol and a water molecule by converting an $\mathrm{H} 2 \mathrm{O} 2$ atom into a natural material such as aromatic products, alkanes, alkenes and fatty acids. (Karich et al., 2017), (Hofrichter et al., 2015). This enzyme has the capacity to conduct one-electrons oxidation, the integration of an oxygen atom into a subsubstratum and the use of $\mathrm{H} 2 \mathrm{O} 2$ as an inter-substratum. (Karich et al., 2017).

\subsubsection{Aryl-alcohol dehydrogenases}

AAD (EC 1.1.1.90) works closely to generate $\mathrm{H} 2 \mathrm{O} 2$ in accordance with the cyclical reddox reactions of the AAO.(Á. T. Martínez et al., 2005). The presence or exposure to aryl-alcohols is responsible for AAD development. (Feldman et al., 2017). AAD forms an aromatic aldehyde in the presence of an aromatic alcohol and a NAD+ receptor. This enzyme shows a high substratum characteristics caused by the catabolism (Yang et al., 2012) 


\subsubsection{Quinone reductases}

Lignin and other aromatic compounds are also reduced by quinone reducctases (EC 1,6.5.5). They aid redox cycling reactions to activate oxygen (Á. T. Martínez et al., 2005). As its name suggests QR, it decreases the presence of NADPH and a hydrogen ion of two quinone molecules creating two half-quinone and NADP+(Lee et al., 2007). Lee et al. (2007) NADH preferences have already been documented as an electron donor and several compounds including $\mathrm{CuSO} 4$, $\mathrm{HgCl} 2, \mathrm{MgSO} 4, \mathrm{MnSO} 4, \mathrm{AgNO} 3, \mathrm{Dicumarol}, \mathrm{KCN}, \mathrm{NaN} 3$, and EDTA can inhibit the intracellular enzyme as an electron donor. In both white and brown red fungi, this enzyme is found (P. C. Guo et al., 2011).

\subsection{Lignocellulolytic enzyme-production by fungi}

Taking advantage of the abundance of biomass and the pressing need for new fuels with less drawbacks than existing choices. As an alternative for its various available application including biofuel production, lignocellulolytic enzyme-producing fungi have been studied. Lignocellulose is an essential structural component in all plants, with cellulose, hemicellulose and lignin being the three main components(M. et al., 2009). Fungi are known to generate various lignocellulolytic enzymes that are also a costly and slow solution.

Although it is not a specific classification system, fungi are classified according to the type of red created. Ascomycets and Deuteromycets are soft-red fungi and occur when the process of white and brown rot has not begun. Soft-rot fungi, while distinguished by degrading timber in severe environment conditions, are the least destructive decomposers. To synthesize enzymes such as cellulases, that mainly break cellulose down from cell walls, they require fixed nitrogen to form microscopic cavities in the secondary cell wall. Withi this group of fungi are Chaetomium globosum, Ceratocystis, Ustulinadeusta, Kretzschmariadeusta, Alternaria alternata, Thielaviaterrestres and Paecilomyces spp. (Á. T. Martínez et al., 2005), (Liers et al., 2011), (Á. T. Martínez et al., 2009).

The three major polymers, lignin, hemicellulose and cellulose, are steadily breaking down white red fungi. White red basidiomycets secrete ligninolytic enzymes for the selective decomposition of lignin: peroxidase manganese, peroxidase lignin, flexible peroxidose and phenol oxidases containing copper (laccase). The most relevant white-rot basidiomycetes are: Auricularia auricula-judae, Agrocybeaegerita, Bjerkanderaadusta, Ceriporiopsissubvermispora, Coprinellusradians, Irpexlacteus, Heterobasidiumannosum, Mycenahaematopus, Phanerochaetechrysosporium, Phlebia radiata, Pleurotuseryngii, Pleurotusostreatus, Pycnoporuscinnabarinus, Stropharia rugosoannulata, Trametes 
International Journal of Agriculture and Environmental Research

ISSN: 2455-6939

Volume: 07, Issue: 01 "January-February 2021"

versicolor and Xylariahypoxylon (A. T. Martínez et al., 2017), (Linde et al., 2015), (FernándezFueyo et al., 2014), (A. Kumar \& Chandra, 2020) (Limaye et al., 2017).

Fungi are less likely to cause brown red than white red. Brown red basidiomycete fungi degrades the major polysaccharide, but first the lignin polymer has to be partly altered and converted into oxidized lignin. The key alteration of lignin due to the brown-rot decay is demethoxylation. The methanol creates peroxide with methanol oxidase overexpression for the treatment of cellulose using Fenton chemistry (Á. T. Martínez et al., 2009). Some of the brown red fungi found are Coniophoraputeana, Gloeophyllumtrabeum, Laetiporussulphureus, Phaeolus schweinitzii Piptoporus betulinus, Postia placenta and Serpula lacrimans (Á. T. Martínez et al., 2009), (Limaye et al., 2017).

Stinch fungi are a small group of Ascomycetes and Deuteromycetes that cause mild resin and parenchyme degradation of the cell wall, affecting extractives and water soluble components. Examples include Ophiostoma, Ceratocystis, Aureobasidium, Phialophora, and other examples. And trichoderma. And Trichoderma spp.(Á. T. Martínez et al., 2005).In addition, some fungal species, mostly in partially decomposed wood, do not form part of a community because of nonspecific rot caused by them.

\subsection{Lignocellulolytic enzyme-production by bacteria}

Although the purpose of the article is not to generate enzymes from bacteria, some examples may be cited. In different organism types, such as plants, bacteria, insecticide and fungi, ligninolytic enzymes are present. The biocatalytical conditions are broader, tolerated by high temperature and $\mathrm{pH}$ concentrations, as well as by chloride; for Bacillus sp up to $600-800 \mathrm{mM}$. WT burden(Paz et al., 2020). Three classes are achieved: actinomycetes, $\alpha$-proteobacteria, and $\mu$ proteobacteria Lignin breaching (Plácido \& Capareda, 2015). Actinomycetes are present for bio-mass degradation within soil or aquatic microflora (Limaye et al., 2017). Its morphology resembles fungi because of its elongated cells that form a structure of filaments or hyphae. Such structures help to degrade by enabling an effective spreading and penetration of organic substances(Limaye et al., 2017). Azospirillumlipoferum, Thermus thermophilus, Marinomonasmediterranea, Bacillus subtilis, and Streptumycescianeus developed Lacc enzymes as examples of actinomyces with Lip activitis enzymes, as well as those produced with Azospirillumlipoferum. (Plácido \& Capareda, 2015). Bacterial laccases are normally intracellular; however, some strains were able to extracellularly express this (Paz et al., 2020). Examples of proteobacteria causing extracellular lip enzymes are Bacillus sp., Pseudomonas sp., Klebsiella pneumonia, Citrobacter sp., and Serratia marcescens (A. Kumar \& Chandra, 2020). 
International Journal of Agriculture and Environmental Research

ISSN: 2455-6939

Volume: 07, Issue: 01 "January-February 2021"

Acid to $\mathrm{pH}$ and temperatures below $50^{\circ} \mathrm{C}$ thrive most widely recognized cellulolytic enzymes. (Bala \& Singh, 2019). However, aerobic, anaerobic, thermophilic and mesophilic bacteria develop cellulolytic enzymes (P. K. Gupta et al., 2019). The thermo- and mesophilic organism and its enzymes have limited phylogenetic diversity (Bala \& Singh, 2019). Due to their potential industrial gain, thermostability, improved resistance to denaturating products and high pressure tolerance, and a rapid degradation of lignocellulosic substrates, many characteristic features emerged in heat cellulases. (Bala \& Singh, 2019).

The synthesis of many cellulolytic enzymes can be achieved either by single enzymes or cellulosomes; (Husain, 2017). Popular cellulases consist of a catalytic field (P. K. Gupta et al., 2019). Genes coding for a cellulose-binding module are common in bacterial and viruses, but uncommon in eukaryotes, adding a second domain to their structure. (Horn et al., 2012); simplifying fungal cellulases as their bacterial equivalent (P. K. Gupta et al., 2019). Bacterial thermophiles including, Clostridium thermocellum, Thermoanaerobacter sp., Clostridium straminisolvens, Thermoanaerobactercurvata and Thermotogamaritima produced cellulases.

\section{PROTEIN ENGINEERING TO IMPROVE ENZYME-BASED CONVERSION}

Because of restrictions on adequate catalytic efficiency, selectivity and stability in $\mathrm{pH}$ and temperature, lignocellulolytic enzymes have struggled in the industry. Some of the above-noted disadvantages can nevertheless be overcome by novel advanced approaches such as enzyme stabilization, substratum technology, structural protein engineering, micro-environment engineering, and advanced computational modelling(Parra-Saldivar et al., 2020).

$\mathrm{pH}$ optimum conditions for most Laccfungalsoscilates between 3,0 and 5,5 and becomes basically inactive as neutral and alkaline $\mathrm{pH}$ values are approached. (Yin et al., 2019). The $\mathrm{pH}$ range is 2.5-3.5 with an activity of comparatively greater than $60 \%$ as $\mathrm{pH}$ rises to 4.0-6.0. activity falls to less than $40 \%$. (J. Guo et al., 2019). The overall $\mathrm{pH}$ values for endoglucanases and $\beta$-glucosidases are 4,0-5,0. (de Souza Lima et al., 2019), (Vazquez-Ortega et al., 2018). Some methods have been tested to resolve $\mathrm{pH}$ stability, such as engineering Lacc modifications by site-directed mutagenesis, showing optimal pH results of 6.5 to 8.5 (Yin et al., 2019); LiP in $\mathrm{Fe} 3 \mathrm{O} 4, \mathrm{SiO} 2$, PDA enzymes were also shown to have improved pH stability in nanoparticles. (J. Guo et al., 2019).

The immobilization of enzyme is also a crucial scientific step towards low thermostability and enzyme rehabilitation. Native enzymes cannot be recovered due to water solubility. (ParraSaldivar et al., 2020). Due to bonds between enzyme and membrane, an increase of 10 percent at $40^{\circ} \mathrm{C}-60^{\circ} \mathrm{C}$ has been recorded. magnetic adsorption can be reused easily (J. Guo et al., 2019). Kaolin immobilised endoglucanases showed improved thermotolerance at $75^{\circ} \mathrm{C}$, relative to free- 
enzyme activity at $45^{\circ}$, and retained maximum activity at $75^{\circ} \mathrm{C}$ (de Souza Lima et al., 2019). Some methods for immobilization by enzymes have been published, such as adsorption, connections, encapsulation, trapping etc. (Parra-Saldivar et al., 2020).

Substratum engineering is an instrument that improves bioconversion and specificity. Efficient promiscuity of substrates results in developing and refining current methods of biodiversisation using lignocellulolytic enzymes (Lairson et al., 2006). As a substrate enzymes can also be engineered, a design of standardized proteins can also be used to produce oligonucleotides, to alter the substrate recognition and selectivity at different functional sites. (Y. Li \& Cirino, 2014).

In comparison, the design of new enzyme architectures is quickly developed and the goal is to improve the catalytic characteristics of enzymes such as activity, selectivity, stability and the specificity of substrates to broader applications. It consists of silicon simulations based on dynamics that accurately recognize the target catalytic regions for results estimation. The complex structural and functional characteristics of enzymes still pose significant unresolved challenges, but some models already have been documented to boost the specificities in part. (Khoury et al., 2009).

Generally, many enhancement techniques are being drawn up to boost the functionalities of enzymes, including inhibition resistance, reusability of the immobilized fractions, hyperactivity/stability, and improved turnover numbers. (Parra-Saldivar et al., 2020), (Bilal et al., 2019).

\section{APPLICATIONS OF CELLULASE, XYLANASE AND LACCASE ENZYMES}

Because of the functions they have, enzymes thrive in various industries. They are present in the textile, dairy, paper and pharmaceutical industries, in bioremediation processes, waste water and so on (Fig-6). They are therefore on company grounds. Cellulase, xylanase and laccape enzymes will be used in more detail because of the purpose of this work.

\subsection{Cellulase enzymes}

Enzymes in various fields of biotechnology are widely used. Because of their catalytic capabilities, many applications are available. Cellulases are used in a number of industrial processes due to their high secretion capability. The most popular applications are: waste, the pulp-and-paper industry, the pharmaceutical industry, emissions, detergents, juice colouring, etc. (Singh et al., 2016), (Fang \& Qu, 2018). 

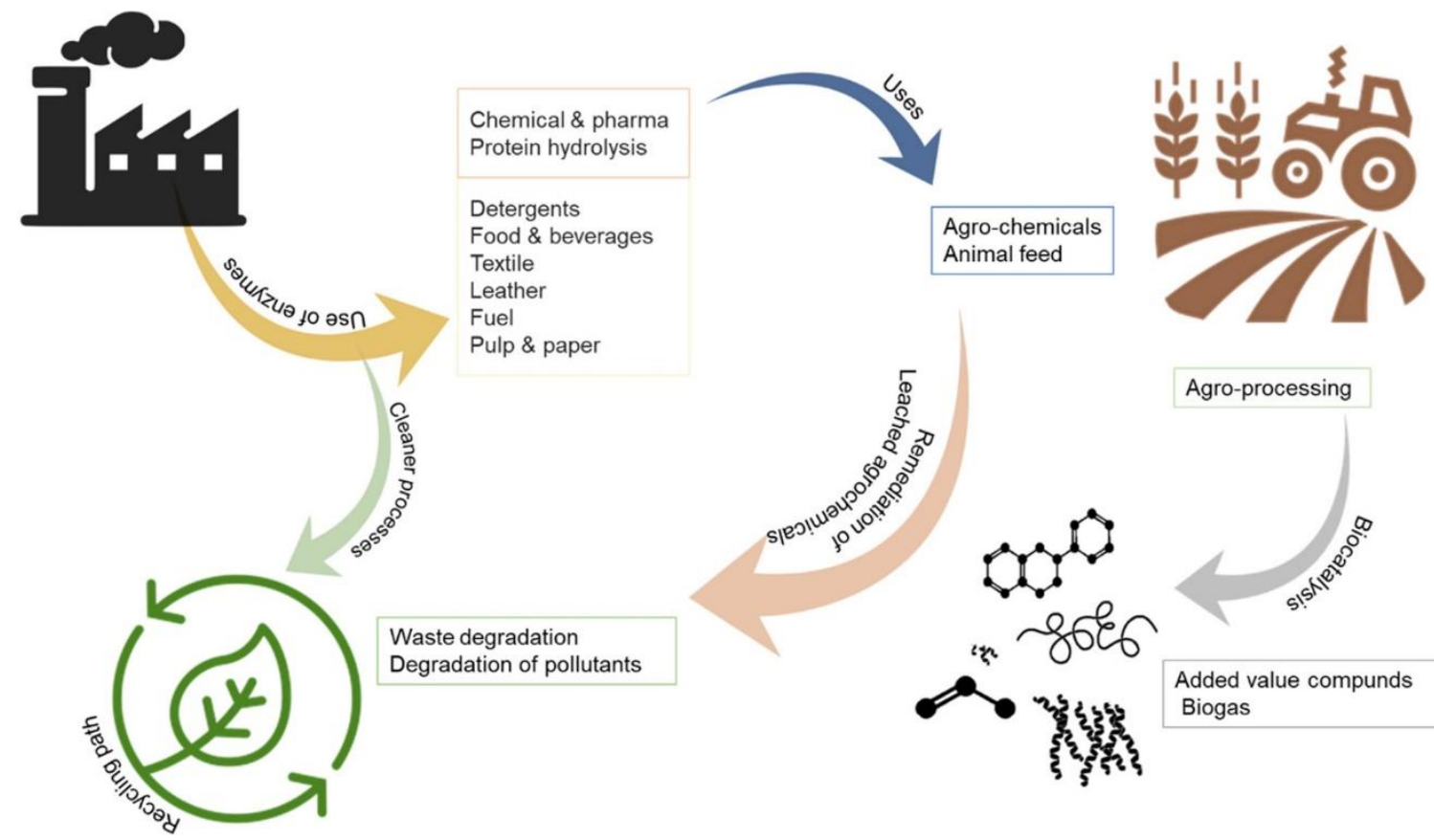

$$
\text { Agro-processing }
$$

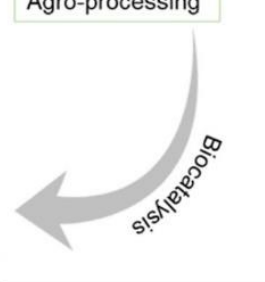

Added value compunds Biogas

Fig. 6: Application of lignocellulolytic enzymes.

Cellulases are commonly used in the food industry to remove compounds of interest and value added, including fruit antioxidants, fruit pumace pigments, seed oil, polysaccharides and proteins of interest. They are also used to recover food additives for usable food and to remove enzymes from the cell wall of the plant biomass. Cellulases are known to promote industrial processes such as fruit juice extraction, clarification of solutions, improved cereal and oats soaking quality, emulsifying purposes, agar extraction and so on from algae. (Fang \& Qu, 2018).

The fermentation, which is applied in the dairy, brewery and wine industries, is another related use of cellulases in fruit. Cellulase improves wine aroma, grape extraction, mashing, malting, and quality beer fermentation (Singh et al., 2016), (Phitsuwan et al., 2013), (Jordan \& Wagschal, 2010).

The animal feed sector is used to supplement monogastric animals and ruminants in pretreatment of lignocellulosic material, i.e. the nutritional properties of animal feed by producing energyintensive foods, by means of cellulases often enhance their digestion. Some innovators have undergone transgenic engineering to detach cellulases directly from their gastrointestinal tract to facilitate lignocellulosic digestion. (Chen et al., 2011), (Herna \& Gutiérrez-soto, 2016), (NiñoMedina et al., 2017), (Iñiguez-Covarrubias et al., 2001). 
International Journal of Agriculture and Environmental Research

ISSN: 2455-6939

Volume: 07, Issue: 01 "January-February 2021"

Excess teint and microfibrils, which remain attached to cotton textiles after a number of washing cycles, have been eliminated by cellulases in the textile industry. They are, however, used to restore fiber color and softness (Kuhad et al., 2011). The production of cellulase-based detergents, which have demonstrated better cleaning behavior compare to other products, while preventing damage to the fabric fibers, is a related application in the detergents industry. In total, cellulases improve color and luminosity and more effectively extract dirt (Fang \& Qu, 2018). The mechanism of plant resistance, in particular the control of pests and diseases, includes cellulases in agriculture. The expression of various proteins, antibodies and enzymes is facilitated by enzymes such as exoglucanases in broad amountions. (Singh et al., 2016).

For cellulases or $\beta$-glucanases capable of degrading the cell walls of plant pathogens, certain cellulolytic microorganisms, such as Penicillium sp., Geocladium sp., Trichoderma sp., and Chaetomium sp. (Singh et al., 2016), (Bhat, 2000). Active interactions between species dominated by Trichoderma sp. Plants allow root condition improvements, seed growth to be enhanced, plant speed growth promoted and crop yields generally improved (Singh et al., 2016).

Cellulases engage in biomechanical pulping in the paper industry, which enables production of biodegradable carton, paper, hygienic paper, towels and other paper products (Singh et al., 2016). Pulp bleaching co-additives, pulping energy needs, improving drainability, reducing chlorine demand for bleaching, fiber brightness improving and enhancing drainage can be used in paper mills cellulase co-additives. (Pathak et al., 2014), (Kuhad et al., 2011), (Kuhad et al., 2016).

In the paper industry, cellulases are involved in biomechanical pulping, allowing the production of biodegradable cardboard, paper, sanitary paper, paper towels and other paper related amenities (Singh et al., 2016). Cellulases are co-additive in pulp bleaching, reduce energy requirements of pulping, improve draining, reduce chlorine requirement for bleaching, improve fiber brightness, can be used for enzymatic deinking and improve drainage in papers mills (Pathak et al., 2014), (Kuhad et al., 2011), (Kuhad et al., 2016).

To get added value compounds and resources, biorefineries are intended to take advantage of raw materials available. In the enzyme helped removal of bioactives as proteins, antioxidants, organic acids, lipids, polysaccharides, phenolic compounds, and even extracellular metabolites such as ethanol, organic solvents, among other products, cellulases have shown significant potential (Carrillo-Nieves et al., 2017), (Nieves et al., 2011), (Nieves et al., 2016). Reduce bioconversion risk of biomass waste. In order to release sugar free after fermentation, cellulases are used to treat second-generation substrates such as bioethanol waste by cellulose depolymerization (An Overview of the Enzyme Potential in Bioenergy-Producing Biorefineries Carlos Escamilla-Alvarado, n.d.). 
International Journal of Agriculture and Environmental Research

ISSN: 2455-6939

Volume: 07, Issue: 01 "January-February 2021"

\subsection{Xylanase enzymes}

By extending its applications in various industries, Xylanases became slowly increasingly popular in biotechnology. In the paper industry, the xylanases make process-paste simpler, improves the efficiency of processes, promote deinking process, and are well known for reducing chlorine consumption by bioblinding kraft pulp. (Pathak et al., 2014), (Phitsuwan et al., 2013). Due to its position in bread quality, the importance of xyllenes has increased in the food industry, with particular emphasis on water absorption and contact with gluten. This helps Xylanase to bind the hemicellulose to a dough that improves durability and softens the dough to make the manipulation of the machinery simpler and the texture of crumbs thinder and uniform. A further use in the food sector is clarification of drinks, extraction of coffee, extraction of vegetable oil and starch and to enhance the dietary features of grain feeds and silages (Phitsuwan et al., 2013). There are few applications in the pharmaceutical industry for xylanases such as dietary use as digestive supplements in conjunction with complex enzymes (hemicellulases, proteases and others). A big current focus is on the development of biofuels such as ethanol, solvents and lowcalorie artificial sweeteners, the transformation of xylans in simpler structures, such as $\beta$-Dxylopyranosyl residues. In the textiles industry, certain xylanolytic enzymes are used for the production of fabrics like hessian or linen. (Polizeli et al., 2005). Its main objective is the structural weakening of the cell walls of the plant. These systemic changes cause changes in the product characteristics of each industry. xylanases are used in the processing of lignocellulosic biomass ethanol, such as cellulases. Lignocellulosic biomass is first deligned with release of hemicelluloses and celluloses; then xylanases are depolymerised to get free sugars that are then fermented for bioethanol (Garg, 2015), (Alvira et al., 2010). The basic role information of xylanases was not specified in each industry.

\subsection{Laccase enzymes}

Laccases are very stable enzymes which can be used in biotechnological processes for a wide range of applications. In the environmental region laccases provide a viable alternative because of their capacity to oxidize phenolic and nontolic compounds and certain highly polluting compounds because of the constante need for oxidation and the undesirable side responses, or non-specific reactions resulting from the use of traditional oxidation technologies. (Rodríguez Couto \& Toca Herrera, 2006). The laccases have relatively low redox potential in comparison to other ligninolytic enzymes $(>1 \mathrm{~V})$ are important to remember. It is not possible to minimize redox. Its action is therefore limited to phenolic lignin oxidation, which constitutes $<20 \%$ of the polymer matrix. Laccase oxidation is not feasible directly from non-phénolic substrates with greater redox potential (e.g. $1.3 \mathrm{~V}$ ). This inconvenience was overcome with redox mediator systems that increase the catalytic activity of non-phenolic lignin components like recalcitrant 
International Journal of Agriculture and Environmental Research

ISSN: 2455-6939

Volume: 07, Issue: 01 "January-February 2021"

(Barreca et al., 2003). The first synthetic mediator to be identified was ABTS (2,2'-azino-bis, 3 ethylbenzothiazoline-6-sulfonic acid)(Abdel-Hamid et al., 2013). There have been examples of other organic, synthetic and natural compounds. However, the mediators that are most important are the ones that occur naturally because they are the most similar to those generated in the environment in the biomass biodegradation. Phenolic compound syringaldehyde, acetosyringon, acetovanillone, vanillin, méthylvanillate and p-coumaric acid are the most commonly studied natural mediators. (Cañas \& Camarero, 2010). It is necessary to consider that laccases need a mediator in order to achieve high conversion rates by lacquer in various industries. Mediators are also inexpensive, eco-friendly and reusable. (Barreca et al., 2003), (Cañas \& Camarero, 2010). It is necessary to consider that laccases need a mediator in order to achieve high conversion rates by lacquer in various industries. Mediators are also inexpensive, eco-friendly and reusable(Ire \& Ahuekwe, 2016). They are also used as food additives, in the manufacture of drinks, biofuels and are therefore known as environmentally friendly biocatalysts (Mate \& Alcalde, 2017). Lacquers in food industries are used to manipulate the color of food by eliminating the unwanted browning of phenolic compound in drinks, including juices, beer and wine (Rodríguez Couto \& Toca Herrera, 2006). Its ability to connect biopolymers is used to reduce the extensibility of wheat dough (Rodríguez Couto \& Toca Herrera, 2006). It was understood that the textile sector used dyes to be replaced by toxic compounds caused by their use and laccases provide a remedy for polluting effluents by bleaching textiles. (Rodríguez Couto \& Toca Herrera, 2006) (SalazarLópez et al., 2017), (Teerapatsakul et al., 2017). The laccases characteristic for polymerizing compound makes it a medium for the environmentally safe synthesization of organic compounds, e.g. aryl-sulfonyl thiazolidinediones, pyrimidobenzothiazoles, catechol thioeters and 2,6-dimethoxyphenol dimmers (Abdel-Hamid et al., 2013). The laccases characteristic for polymerizing compound makes it a medium for the environmentally safe synthesization of organic compounds, e.g. aryl-sulfonyl thiazolidinediones, pyrimidobenzothiazoles, catechol thioeters and 2,6-dimethoxyphenol dimers (Rodríguez Couto \& Toca Herrera, 2006). The laccases have demonstrated their ability to combine a range of molecules to create new low molecular compounds, such as antibiotics, amino acids, antioxidants and high-render cytostatic(Mikolasch \& Schauer, 2009). Lacases have been used in recent years as a method to biotransform or biodegrade emerging pollutants (Barrios-Estrada, de Jesús Rostro-Alanis, et al., 2018)For eg, nonyl phenol, triclosan, Bisphenol A, Ethynylestradiol, Diclofenac sodium, $\beta$ naphthol, 2,4-dichlorophenol, m-cresol and more DI-Diiodo-8-hydroxyquinoline (RamírezCavazos et al., 2014), (M. Rodríguez-Delgado et al., 2016), (Gonzalez-Coronel et al., 2017), (Barrios-Estrada, Rostro-Alanis, et al., 2018). Recently the use of lacases as catechol determination biosensors, polyphenol identification in various samples, $17 \beta$-stradiol determination, 2,6-dimethoxyphenol measurement in wastewater and the determination of Ltyrosinases in aqueous solutions have been published, and more recently (Abdel-Hamid et al., 
International Journal of Agriculture and Environmental Research

ISSN: 2455-6939

Volume: 07, Issue: 01 "January-February 2021"

2013), (M. M. Rodríguez-Delgado et al., 2015) Laccases for the formation of bioelectric cells are also being studied (Abdel-Hamid et al., 2013).

\section{CURRENT SEARCH IN MEXICO FOR MICROORGANISMS THAT EFFICIENTLY DEGRADE LIGNOCELLULOSIC MATERIALS}

Many species are devoid of enzyme systems required because of their complexity to thoroughly degrade the lignocellulosic material. The individuals that can be found in the scientific community around the world (Dhevagi Periasamy, Sudhakarn Mani, 2019), (Niño-Medina et al., 2017). During this time, many microorganisms lack enzyme systems which are required for the successful degradation of lignocellulosic material due to the complex cell wall model of Lignocellulosic Biomass. While Mexico is one of the countries with the greatest diversity of fungi, with more than 140,000 species, it has been studied with a very restricted quest for certain producers of enzymes of biotechnological significance. Nuevo León's researchers are from Mexico (Herna \& Gutiérrez-soto, 2016) (Niño-Medina et al., 2017), Hidalgo, Jalisco, Yucatán (Cruz-Ornelas et al., 2019), (Amaya-Delgado et al., 2010) and Veracruz (Dhevagi Periasamy, Sudhakarn Mani, 2019), (Cupul et al., 2014) The greatest number of described fungal species have been reported; however, the information is still profound.

Niño-Medina and others have measured the effect on the physicochemical properties of bread, extracted from Trametes maximaCU1 native fungus from Cerro La Silla, Nuevo León (NiñoMedina et al., 2017). 60 thermotolerant-isolated fungi from Hidalgo display a strong lacquer function, which according to Cruz Ramírez et al. has a biotechnological potential (Cruz Ramírez et al., 2012).

The expression of the enzyme lignin-cellulolytic Pleurotusdjamor, a white-red fungus widely spread in Mexico, was found. A recent application to extract diclofenac, naproxen and ketoprofen from aquatic cultures has been demonstrated by the degradations of enzymes such as laccases, manganese perojidases and lignin peroxidase. (Cruz-Ornelas et al., 2019).

Chan Cupul et al., 70 fungal species isolated, including Trametes maximum SM9, Pycnoporussanguineus ACT1 and Dedalea elegans PM7, from the state of Veracruz. Qualitative and quantitative assessments and liquid and solid fermentation in Agar plates were conducted respectively. Enzyme activity, particularly lacquer and $\mathrm{MnP}$, showed an expression of results(Dhevagi Periasamy, Sudhakarn Mani, 2019). That is why T is concluded. Maximum SM9 and P. sanguineus ACT1 are successful productivity candidates. 


\section{RESEARCH GAPS CHALLENGES AND RECOMMENDATIONS}

For its full enzymatic hydrolysis, the heterogeneity of lignocellulosic biomass represents many challenges. The saccharging capability of the enzyme is impaired by factors such as thermal instability of protein, substrate excess inhibition, unspecific polymer chain binding and irreversible lignin adsorption. As a result, undegraded residues are important post-treatment and thus not cost-effective. The purification of enzymes has a huge impact on the increased cost of production and sale.

The ongoing studies to isolate higher-activity improved cellulases and stability in severe temperature environments, $\mathrm{pH}$, etc. aim at enhancing the cost-effectiveness of the method as opposed to those that are currently usable. The main emphasis is on reducing manufacturing costs from 10 to 100 times. Due to the lack of all unique enzyme groups needed to efficient degradation in most microorganisms, several technologies have been combined to achieve the desired results. Genetic and metabolism strategies for the assembly of new enzymes capable of hydrolyzing a wide range of polysaccharide bonds, combined with a high activity dependent selection and combination of many enzymes, the complex structure of lignocellulosic biomass would be fully degraded to their monomeric forms. Several enzyme manufacturing multinationals are now creating cellulase cocktails to express desired mixtures.In other words, transformed microorganisms need genetic instruments to increase lignocellulolytic enzyme production. Genetic changes regulated will lead to a more cost effective and efficient manufacturing process. Mutagenesis on the site causes the specificity of the substrate to increase and the base properties to exceed. Transcriptomic technologies promote understanding of and impact on gene expression, regulation and networks on the genome's reaction to environmental disorders, which represents an advantage in enzyme expression that factors such as temperature and $\mathrm{pH}$ can easily alter.Therefore, a greater understanding of the expression and development of lignocellulolytic enzymes is made possible by the metabolic pathways and the genetic regulatory mechanism, which therefore contributes to optimization.

\section{CONCLUSION}

The world's abundant biodiversity of fungi providing a variety of enzymes with the catalytic capacity to carry out lignocellulosic biomass hydrolysis is an encouraged method and an environmental option for the revalorization of lignocellulolytic materials from agro-industrial waste. Because of the incorporation of autochthonous enzymes produced in a wide range of countries, research in this field would trigger favorable changes in the enzyme market with cost reductions.In order to boost the saccharification of lignocellulosic biomass by enzyme hydrolysis, new technologies need to be introduced, including genetic modification of microorganisms to increase the yield of enzyme output in a cost-effective manner, as well as 
International Journal of Agriculture and Environmental Research

ISSN: 2455-6939

Volume: 07, Issue: 01 "January-February 2021"

predictions of genetic expression and transcriptomic metabolic responses. In the near future, the total degradation of lignocellulosic biomass by enzymes generated by fungi to create a wide variety of new products will be a reality. The ability of enzymes would pose new challenges in terms of commercial development, the cost of enzymes and the variety of enzyme cocktails appropriate for agro-industrial waste used as substrates and for new products in the light of the sustainable production of new products worldwide. The use of industrial enzymes for the hydrolysis of lignocellulosic substrates greatly improves the method of enzymatic application, as well as the manufacturing method of second-generation bioethanol. Thus, the discovery of new enzymes obtained from native Mexican fungal strains with high enzyme productivity and low production costs, using agricultural waste substrates, significantly stimulates the production of lignocellulolytic enzymes in situ. One of the major challenges in the industrial production of enzymes is the creation of the tailored, cost-effective and sequential action of a cocktail of enzymes with a high specific activity that allows the complete degradation of the complex structure of lignocellulosic biomass to its monomeric forms.

\section{REFERENCES}

1. Abdel-Hamid, A. M., Solbiati, J. O., \& Cann, I. K. O. (2013). Insights into Lignin Degradation and its Potential Industrial Applications. In Advances in Applied Microbiology (Vol. 82). Elsevier. https://doi.org/10.1016/B978-0-12-407679-2.00001-6

2. Adebami, G. E., \& Adebayo-Tayo, B. C. (2020). Development of cellulolytic strain by genetic engineering approach for enhanced cellulase production. In Genetic and Metabolic Engineering for Improved Biofuel Production from Lignocellulosic Biomass. Elsevier Inc. https://doi.org/10.1016/b978-0-12-817953-6.00008-7

3. Adesioye, F. A., Makhalanyane, T. P., Biely, P., \& Cowan, D. A. (2016). Phylogeny, classification and metagenomic bioprospecting of microbial acetyl xylan esterases. Enzyme and Microbial Technology, 93-94, 79-91. https://doi.org/10.1016/j.enzmictec.2016.07.001

4. Alvira, P., Tomás-Pejó, E., Ballesteros, M., \& Negro, M. J. (2010). Pretreatment technologies for an efficient bioethanol production process based on enzymatic hydrolysis: A review. Bioresource Technology, 101(13), 4851-4861. https://doi.org/10.1016/j.biortech.2009.11.093

5. Amaya-Delgado, L., Mejía-Castillo, T., Santiago-Hernández, A., Vega-Estrada, J., Amelia, F. G. S., Xoconostle-Cázares, B., Ruiz-Medrano, R., Montes-Horcasitas, M. del C., \& Hidalgo-Lara, M. E. (2010). Cloning and expression of a novel, moderately thermostable xylanase-encoding gene ( $\mathrm{Cfl}$ xyn11A) from Cellulomonas flavigena. Bioresource Technology, 101(14), 5539-5545. https://doi.org/10.1016/j.biortech.2010.02.057 
International Journal of Agriculture and Environmental Research

ISSN: 2455-6939

Volume: 07, Issue: 01 "January-February 2021"

6. An overview of the enzyme potential in bioenergy-producing biorefineries Carlos Escamilla-Alvarado. (n.d.).

7. Anwar, Z., Gulfraz, M., \& Irshad, M. (2014). Agro-industrial lignocellulosic biomass a key to unlock the future bio-energy: A brief review. Journal of Radiation Research and Applied Sciences, 7(2), 163-173. https://doi.org/10.1016/j.jrras.2014.02.003

8. Arrieta, M. P., López, J., López, D., Kenny, J. M., \& Peponi, L. (2016). Biodegradable electrospun bionanocomposite fibers based on plasticized PLA-PHB blends reinforced with cellulose nanocrystals. Industrial Crops and Products, 93, 290-301. https://doi.org/10.1016/j.indcrop.2015.12.058

9. Asgher, M., Ahmad, Z., \& Iqbal, H. M. N. (2013). Alkali and enzymatic delignification of sugarcane bagasse to expose cellulose polymers for saccharification and bio-ethanol production. Industrial Crops and Products, 44, 488-495. https://doi.org/10.1016/j.indcrop.2012.10.005

10. Asgher, M., Bhatti, H. N., Ashraf, M., \& Legge, R. L. (2008). Recent developments in biodegradation of industrial pollutants by white rot fungi and their enzyme system. Biodegradation, 19(6), 771-783. https://doi.org/10.1007/s10532-008-9185-3

11. Asier, D. :, Blanco, M., Bío-bío, U. D. E. L., Ingeniería, F. D. E., Compuesto, M., Lignina, P., Velásquez Restrepo, S. M., Peaéz Arroyave, G. J., Giraldo Vásquez, D., Chávez Sifontes, M., \& Domine, M. E. (2010). Uso de fibras vegetales en materiales compuestos de matriz polimérica : una revisión con miras a su aplicación en el diseño de nuevos productos Use of vegetable fibers in polymer matrix composites: a review. Avances En Ciencias e Ingeniería, ISSN-e 0718-8706, Vol. 4, No. 4, 2013, Págs. 15-46, 4(4), 77-86.

12. Asim, A. M., Uroos, M., Naz, S., Sultan, M., Griffin, G., Muhammad, N., \& Khan, A. S. (2019). Acidic ionic liquids: Promising and cost-effective solvents for processing of lignocellulosic biomass. Journal of Molecular Liquids, 287. https://doi.org/10.1016/j.molliq.2019.110943

13. Bak, J. S., Ko, J. K., Choi, I. G., Park, Y. C., Seo, J. H., \& Kim, K. H. (2009). Fungal pretreatment of lignocellulose by Phanerochaete chrysosporium to produce ethanol from rice straw. Biotechnology and Bioengineering, 104(3), 471-482. https://doi.org/10.1002/bit.22423

14. Bala, A., \& Singh, B. (2019). Cellulolytic and xylanolytic enzymes of thermophiles for the production of renewable biofuels. Renewable Energy, 136, 1231-1244. https://doi.org/10.1016/j.renene.2018.09.100

15. Barreca, A. M., Fabbrini, M., Galli, C., Gentili, P., \& Ljunggren, S. (2003). Laccase/mediated oxidation of a lignin model for improved delignification procedures. Journal of Molecular Catalysis B: Enzymatic, 26(1-2), 105-110. 
International Journal of Agriculture and Environmental Research

ISSN: 2455-6939

Volume: 07, Issue: 01 "January-February 2021"

https://doi.org/10.1016/j.molcatb.2003.08.001

16. Barrios-Estrada, C., de Jesús Rostro-Alanis, M., Muñoz-Gutiérrez, B. D., Iqbal, H. M. N., Kannan, S., \& Parra-Saldívar, R. (2018). Emergent contaminants: Endocrine disruptors and their laccase-assisted degradation - A review. Science of the Total Environment, 612, 1516-1531. https://doi.org/10.1016/j.scitotenv.2017.09.013

17. Barrios-Estrada, C., Rostro-Alanis, M. de J., Parra, A. L., Belleville, M. P., SanchezMarcano, J., Iqbal, H. M. N., \& Parra-Saldívar, R. (2018). Potentialities of active membranes with immobilized laccase for Bisphenol A degradation. International Journal of Biological Macromolecules, $108, \quad 837-844$. https://doi.org/10.1016/j.ijbiomac.2017.10.177

18. Bennett, A. B. (2003). Out of the Amazon: Theobroma cacao enters the genomic era. Trends in Plant Science, 8(12), 561-563. https://doi.org/10.1016/j.tplants.2003.10.004

19. Bhat, M. K. (2000). Cellulases and related enzymes in biotechnology. Biotechnology Advances, 18(5), 355-383. https://doi.org/10.1016/S0734-9750(00)00041-0

20. Bhatt, S. M., \& Shilpa. (2014). Lignocellulosic feedstock conversion, inhibitor detoxification and cellulosic hydrolysis - A review. Biofuels, 5(6), 633-649. https://doi.org/10.1080/17597269.2014.1003702

21. Bilal, M., Cui, J., \& Iqbal, H. M. N. (2019). Tailoring enzyme microenvironment: Stateof-the-art strategy to fulfill the quest for efficient bio-catalysis. International Journal of Biological Macromolecules, 130, 186-196. https://doi.org/10.1016/j.ijbiomac.2019.02.141

22. Broeker, J., Mechelke, M., Baudrexl, M., Mennerich, D., Hornburg, D., Mann, M., Schwarz, W. H., Liebl, W., \& Zverlov, V. V. (2018). The hemicellulose-degrading enzyme system of the thermophilic bacterium Clostridium stercorarium: Comparative characterisation and addition of new hemicellulolytic glycoside hydrolases. Biotechnology for Biofuels, 11(1), 1-18. https://doi.org/10.1186/s13068-018-1228-3

23. Brum, M. C., Araújo, W. L., Maki, C. S., \& Azevedo, J. L. (2012). Endophytic fungi from Vitis labrusca L. ('Niagara Rosada') and its potential for the biological control of Fusarium oxysporum. Genetics and Molecular Research: GMR, 11(4), 4187-4197. https://doi.org/10.4238/2012.December.6.2

24. Camacho-Morales, R. L., Gerardo-Gerardo, J. L., Guillén Navarro, K., \& Sánchez, J. E. (2017). Ligninolytic enzyme production by white rot fungi during paraquat (herbicide) degradation. Revista Argentina de Microbiologia, 49(2), 189-196. https://doi.org/10.1016/j.ram.2016.11.004

25. Camarero, S., Sarkar, S., Ruiz-Dueñas, F. J., Martínez, M. J., \& Martínez, Á. T. (1999). Description of a versatile peroxidase involved in the natural degradation of lignin that has both manganese peroxidase and lignin peroxidase substrate interaction sites. Journal of 
International Journal of Agriculture and Environmental Research

ISSN: 2455-6939

Volume: 07, Issue: 01 "January-February 2021"

Biological Chemistry, 274(15), 10324-10330. https://doi.org/10.1074/jbc.274.15.10324

26. Cañas, A. I., \& Camarero, S. (2010). Laccases and their natural mediators: Biotechnological tools for sustainable eco-friendly processes. Biotechnology Advances, 28(6), 694-705. https://doi.org/10.1016/j.biotechadv.2010.05.002

27. Carli, S., Meleiro, L. P., Rosa, J. C., Moraes, L. A. B., Jorge, J. A., Masui, D. C., \& Furriel, R. P. M. (2016). A novel thermostable and halotolerant xylanase from Colletotrichum graminicola. Journal of Molecular Catalysis B: Enzymatic, 133(2016), S508-S517. https://doi.org/10.1016/j.molcatb.2017.05.002

28. Carrillo-Nieves, D., Ruiz, H. A., Aguilar, C. N., Ilyina, A., Parra-Saldivar, R., Torres, J. A., \& Martínez Hernández, J. L. (2017). Process alternatives for bioethanol production from mango stem bark residues. Bioresource Technology, 239, 430-436. https://doi.org/10.1016/j.biortech.2017.04.131

29. Carro, J., Ferreira, P., Rodríguez, L., Prieto, A., Serrano, A., Balcells, B., Ardá, A., Jiménez-Barbero, J., Gutiérrez, A., Ullrich, R., Hofrichter, M., \& Martínez, A. T. (2015). 5-Hydroxymethylfurfural Conversion By Fungal Aryl-Alcohol Oxidase and Unspecific Peroxygenase. FEBS Journal, 282(16), 3218-3229. https://doi.org/10.1111/febs.13177

30. Chapman, J., Ismail, A. E., \& Dinu, C. Z. (2018). Industrial applications of enzymes: Recent advances, techniques, and outlooks. Catalysts, 8(6), 20-29. https://doi.org/10.3390/catal8060238

31. Chatterjee, C., Pong, F., \& Sen, A. (2015). Chemical conversion pathways for carbohydrates. Green Chemistry, 17(1), 40-71. https://doi.org/10.1039/c4gc01062k

32. Chen, H., He, Q., \& Liu, L. (2011). Cellulase production from the corn stover fraction based on the organ and tissue. Biotechnology and Bioprocess Engineering, 16(5), 867874. https://doi.org/10.1007/s12257-011-0171-y

33. Cruz-Ornelas, R., Sánchez-Vázquez, J. E., Amaya-Delgado, L., Guillén-Navarro, K., \& Calixto-Romo, A. (2019). Biodegradation of NSAIDs and their effect on the activity of ligninolytic enzymes from Pleurotus djamor. 3 Biotech, 9(10), 1-8. https://doi.org/10.1007/s13205-019-1904-4

34. Cruz Ramírez, M. G., Rivera-Ríos, J. M., Téllez-Jurado, A., Maqueda Gálvez, A. P., Mercado-Flores, Y., \& Arana-Cuenca, A. (2012). Screening for thermotolerant ligninolytic fungi with laccase, lipase, and protease activity isolated in Mexico. Journal of Environmental Management, 95(SUPPL.), S256-S259. https://doi.org/10.1016/j.jenvman.2010.10.045

35. Cupul, W. C., Abarca, G. H., Carrera, D. M., \& Vázquez, R. R. (2014). Enhancement of ligninolytic enzyme activities in a Trametes maxima-Paecilomyces carneus co-culture: Key factors revealed after screening using a Plackett-Burman experimental design. Electronic Journal of Biotechnology, $17(3), \quad 1-8$. 
International Journal of Agriculture and Environmental Research

ISSN: 2455-6939

Volume: 07, Issue: 01 "January-February 2021"

https://doi.org/10.1016/j.ejbt.2014.04.007

36. Damm, T., Commandeur, U., Fischer, R., Usadel, B., \& Klose, H. (2016). Improving the utilization of lignocellulosic biomass by polysaccharide modification. Process Biochemistry, 51(2), 288-296. https://doi.org/10.1016/j.procbio.2015.12.003

37. Daou, M., \& Faulds, C. B. (2017). Glyoxal oxidases: their nature and properties. World Journal of Microbiology and Biotechnology, 33(5), 0. https://doi.org/10.1007/s11274017-2254-1

38. Davis, K. M., Rover, M., Brown, R. C., Bai, X., Wen, Z., \& Jarboe, L. R. (2016). Recovery and utilization of lignin monomers as part of the biorefinery approach. Energies, 9(10), 1-28. https://doi.org/10.3390/en9100808

39. de Souza Lima, J., Costa, F. N., Bastistella, M. A., de Araújo, P. H. H., \& de Oliveira, D. (2019). Functionalized kaolin as support for endoglucanase immobilization. Bioprocess and Biosystems Engineering, 42(7), 1165-1173. https://doi.org/10.1007/s00449-01902113-w

40. Dhevagi Periasamy, Sudhakarn Mani, and R. A. (2019). Chapter 4 White Rot Fungi and Their Enzymes for the Treatment of Industrial Dye Effluents. In:Nath A, Singh YS, Mishra S, Gupta A.(eds)Fungal Biology Recent Advancement in White Biotechnology Through Fungi . 3(October), 73-100. https://doi.org/10.1007/978-3-030-10480-1

41. Dornez, E., Gebruers, K., Cuyvers, S., Delcour, J. A., \& Courtin, C. M. (2007). Impact of wheat flour-associated endoxylanases on arabinoxylan in dough after mixing and resting. Journal of Agricultural and Food Chemistry, 55(17), 7149-7155. https://doi.org/10.1021/jf071363m

42. Dsm, R. (2019). Global industrial enzymes market to 2024. Focus on Surfactants, 2019(6), 4. https://doi.org/10.1016/j.fos.2019.06.019

43. Durães Sette, L., \& Costa Bonugli Santos, R. (2013). Ligninolytic enzymes from marinederived fungi: Production and applications. In Marine Enzymes for Biocatalysis: Sources, Biocatalytic Characteristics and Bioprocesses of Marine Enzymes. Woodhead Publishing Limited. https://doi.org/10.1533/9781908818355.3.403

44. Eggert, C., Temp, U., Dean, J. F. D., \& Eriksson, K. E. L. (1996). A fungal metabolite mediates degradation of non-phenolic lignin structures and synthetic lignin by laccase. FEBS Letters, 391(1-2), 144-148. https://doi.org/10.1016/0014-5793(96)00719-3

45. Eronen, P., Österberg, M., Heikkinen, S., Tenkanen, M., \& Laine, J. (2011). Interactions of structurally different hemicelluloses with nanofibrillar cellulose. Carbohydrate Polymers, 86(3), 1281-1290. https://doi.org/10.1016/j.carbpol.2011.06.031

46. Fang, X., \& Qu, Y. (2018). Fungal cellulolytic enzymes: Microbial production and application. Fungal Cellulolytic Enzymes: Microbial Production and Application, 1-282. https://doi.org/10.1007/978-981-13-0749-2 
International Journal of Agriculture and Environmental Research

ISSN: 2455-6939

Volume: 07, Issue: 01 "January-February 2021"

47. Feldman, D., Kowbel, D. J., Glass, N. L., Yarden, O., \& Hadar, Y. (2017). A role for small secreted proteins (SSPs) in a saprophytic fungal lifestyle: Ligninolytic enzyme regulation in Pleurotus ostreatus. Scientific Reports, 7(1), 1-13. https://doi.org/10.1038/s41598-017-15112-2

48. Fernández-Fueyo, E., Castanera, R., Ruiz-Dueñas, F. J., López-Lucendo, M. F., Ramírez, L., Pisabarro, A. G., \& Martínez, A. T. (2014). Ligninolytic peroxidase gene expression by Pleurotus ostreatus: Differential regulation in lignocellulose medium and effect of temperature and $\mathrm{pH}$. Fungal Genetics and Biology, 72, 150-161. https://doi.org/10.1016/j.fgb.2014.02.003

49. Ferreira, P., Hernandez-Ortega, A., Herguedas, B., Martínez, Á. T., \& Medina, M. (2009). Aryl-alcohol oxidase involved in lignin degradation. A mechanistic study based on steady and pre-steady state kinetics and primary and solvent isotope effects with two alcohol substrates. Journal of Biological Chemistry, 284(37), 24840-24847. https://doi.org/10.1074/jbc.M109.011593

50. Frade, R. F. M., \& Afonso, C. A. M. (2010). Impact of ionic liquids in environment and humans: An overview. Human and Experimental Toxicology, 29(12), 1038-1054. https://doi.org/10.1177/0960327110371259

51. Frazer, L. N. (1999). One stop mycology. Mycological Research, 103(1), 116-128. https://doi.org/10.1017/s0953756298007771

52. Frommhagen, M., Mutte, S. K., Westphal, A. H., Koetsier, M. J., Hinz, S. W. A., Visser, J., Vincken, J. P., Weijers, D., Van Berkel, W. J. H., Gruppen, H., \& Kabel, M. A. (2017). Boosting LPMO-driven lignocellulose degradation by polyphenol oxidaseactivated lignin building blocks. Biotechnology for Biofuels, 10(1), 1-16. https://doi.org/10.1186/s13068-017-0810-4

53. Garcia-Maraver, A., Salvachúa, D., Martínez, M. J., Diaz, L. F., \& Zamorano, M. (2013). Analysis of the relation between the cellulose, hemicellulose and lignin content and the thermal behavior of residual biomass from olive trees. Waste Management, 33(11), 22452249. https://doi.org/10.1016/j.wasman.2013.07.010

54. Garg, S. (2015). Xylanase: Applications in Biofuel Production. Current Metabolomics, 4(1), 23-37. https://doi.org/10.2174/2213235x03666150915211224

55. Ghosh, M., Prajapati, B. P., Suryawanshi, R. K., Kishor Dey, K., \& Kango, N. (2019). Study of the effect of enzymatic deconstruction on natural cellulose by NMR measurements. Chemical Physics Letters, 727(March), 105-115. https://doi.org/10.1016/j.cplett.2019.04.063

56. Gilbert, H. J., Stålbrand, H., \& Brumer, H. (2008). How the walls come crumbling down: recent structural biochemistry of plant polysaccharide degradation. Current Opinion in Plant Biology, 11(3), 338-348. https://doi.org/10.1016/j.pbi.2008.03.004 
International Journal of Agriculture and Environmental Research

ISSN: 2455-6939

Volume: 07, Issue: 01 "January-February 2021"

57. Gonzalez-Coronel, L. A., Cobas, M., Rostro-Alanis, M. de J., Parra-Saldívar, R., Hernandez-Luna, C., Pazos, M., \& Sanromán, M. Á. (2017). Immobilization of laccase of Pycnoporus sanguineus CS43. New Biotechnology, 39, 141-149. https://doi.org/10.1016/j.nbt.2016.12.003

58. Gu, T., Held, M. A., \& Faik, A. (2013). Supercritical CO2 and ionic liquids for the pretreatment of lignocellulosic biomass in bioethanol production. Environmental Technology (United Kingdom), 34(13-14), 1735-1749. https://doi.org/10.1080/09593330.2013.809777

59. Guerriero, G., Hausman, J. F., Strauss, J., Ertan, H., \& Siddiqui, K. S. (2016). Lignocellulosic biomass: Biosynthesis, degradation,. Engineering in Life Sciences, 16(1), 1-16. https://doi.org/10.1002/elsc.201400196

60. Guo, J., Liu, X., Zhang, X., Wu, J., Chai, C., Ma, D., Chen, Q., Xiang, D., \& Ge, W. (2019). Immobilized lignin peroxidase on Fe3O4@SiO2@polydopamine nanoparticles for degradation of organic pollutants. International Journal of Biological Macromolecules, 138, 433-440. https://doi.org/10.1016/j.ijbiomac.2019.07.105

61. Guo, P. C., Ma, X. X., Bao, Z. Z., Ma, J. Di, Chen, Y., \& Zhou, C. Z. (2011). Structural insights into the cofactor-assisted substrate recognition of yeast quinone oxidoreductase Zta1. Journal of Structural Biology, 176(1), 112-118. https://doi.org/10.1016/j.jsb.2011.07.010

62. Gupta, P. K., Choudhary, S., Chandrananthi, C., Sharon Eveline, J., \& Sushmitha, S. P. (2019). Fungal Biodiversity Producing Cellulase Involved in Efficient Cellulolysis. November, 23-33. https://doi.org/10.1007/978-3-030-23834-6_2

63. Gupta, V. K., Kubicek, C. P., Berrin, J. G., Wilson, D. W., Couturier, M., Berlin, A., Filho, E. X. F., \& Ezeji, T. (2016). Fungal Enzymes for Bio-Products from Sustainable and Waste Biomass. Trends in Biochemical Sciences, 41(7), 633-645. https://doi.org/10.1016/j.tibs.2016.04.006

64. Haghighi Mood, S., Hossein Golfeshan, A., Tabatabaei, M., Salehi Jouzani, G., Najafi, G. H., Gholami, M., \& Ardjmand, M. (2013). Lignocellulosic biomass to bioethanol, a comprehensive review with a focus on pretreatment. Renewable and Sustainable Energy Reviews, 27, 77-93. https://doi.org/10.1016/j.rser.2013.06.033

65. He, J., Yin, J., Wang, L., Yu, B., \& Chen, D. (2010). Functional characterisation of a recombinant xylanase from Pichia pastoris and effect of the enzyme on nutrient digestibility in weaned pigs. British Journal of Nutrition, 103(10), 1507-1513. https://doi.org/10.1017/S0007114509993333

66. Herna, C. A., \& Gutiérrez-soto, G. (2016). Uso de basidiomicetos nativos en la biotransformación del pasto buffel (Cenchrus ciliaris) para mejorar la calidad nutricional. Revista Mexicana de Micología, 43, 31-35. 
International Journal of Agriculture and Environmental Research

ISSN: 2455-6939

Volume: 07, Issue: 01 "January-February 2021"

67. Hofrichter, M., Kellner, H., Pecyna, M. J., \& Ullrich, R. (2015). Fungal unspecific peroxygenases: Heme-thiolate proteins that combine peroxidase and cytochrome P450 properties. In Advances in Experimental Medicine and Biology (Vol. 851). https://doi.org/10.1007/978-3-319-16009-2_13

68. Horn, S. J., Vaaje-Kolstad, G., Westereng, B., \& Eijsink, V. G. H. (2012). Novel enzymes for the degradation of cellulose. Biotechnology for Biofuels, 5. https://doi.org/10.1186/1754-6834-5-45

69. Hosseini, S. A., \& Shah, N. (2011). Modelling enzymatic hydrolysis of cellulose part I: Population balance modelling of hydrolysis by endoglucanase. Biomass and Bioenergy, 35(9), 3841-3848. https://doi.org/10.1016/j.biombioe.2011.04.026

70. Husain, Q. (2017). Central Bringing Excellence in Open Access Nanomaterials Immobilized Cellulolytic Enzymes and their Industrial Applications: A Literature Review. Nanomaterials Immobilized Cellulolytic Enzymes and Their Industrial Applications: A Literature Review. JSM Biochem Mol Biol, 4(3), 1029.

71. Ibn Yaich, A., Edlund, U., \& Albertsson, A. C. (2017). Transfer of Biomatrix/Wood Cell Interactions to Hemicellulose-Based Materials to Control Water Interaction. Chemical Reviews, 117(12), 8177-8207. https://doi.org/10.1021/acs.chemrev.6b00841

72. Ingle, A. P., Chandel, A. K., Antunes, F. A. F., Rai, M., \& da Silva, S. S. (2019). New trends in application of nanotechnology for the pretreatment of lignocellulosic biomass. Biofuels, Bioproducts and Biorefining, 13(3), 776-788. https://doi.org/10.1002/bbb.1965

73. Iñiguez-Covarrubias, G., Lange, S. E., \& Rowell, R. M. (2001). Utilization of byproducts from the tequila industry: Part 1: Agave bagasse as a raw material for animal feeding and fiberboard production. Bioresource Technology, 77(1), 25-32. https://doi.org/10.1016/S0960-8524(00)00137-1

74. Iqbal, H. M. N., Ahmed, I., Zia, M. A., \& Irfan, M. (2011). Purification and characterization of the kinetic parameters of cellulase produced from wheat straw by Trichoderma viride under SSF and its detergent compatibility. Advances in Bioscience and Biotechnology, 02(03), 149-156. https://doi.org/10.4236/abb.2011.23024

75. Ire, F., \& Ahuekwe, E. (2016). Production of Fungal Laccase Using Orange Peelings as Substrate by Submerged Static Fermentation. British Microbiology Research Journal, 15(5), 1-19. https://doi.org/10.9734/bmrj/2016/27257

76. Jahnavi, G., Prashanthi, G. S., Sravanthi, K., \& Rao, L. V. (2017). Status of availability of lignocellulosic feed stocks in India: Biotechnological strategies involved in the production of Bioethanol. Renewable and Sustainable Energy Reviews, 73(February), 798-820. https://doi.org/10.1016/j.rser.2017.02.018

77. Jaramillo, P. M. D., Gomes, H. A. R., Monclaro, A. V, Silva, C. O. G., \& Filho, E. X. F. (n.d.). Section 2 Production of recombinant peptides Chapter 6 Lignocellulose - 
International Journal of Agriculture and Environmental Research

ISSN: 2455-6939

Volume: 07, Issue: 01 "January-February 2021"

degrading enzymes: An overview of the global market.

78. Jayasekara, S., \& Ratnayake, R. (2019). Microbial Cellulases: An Overview and Applications. Cellulose. https://doi.org/10.5772/intechopen.84531

79. Jia, L., Qin, Y., Wang, J., \& Zhang, J. (2020). Lignin extracted by $\gamma$-valerolactone/water from corn stover improves cellulose enzymatic hydrolysis. Bioresource Technology, 302(3), 122901. https://doi.org/10.1016/j.biortech.2020.122901

80. Jordan, D. B., \& Wagschal, K. (2010). Properties and applications of microbial $\beta$-Dxylosidases featuring the catalytically efficient enzyme from Selenomonas ruminantium. Applied Microbiology and Biotechnology, 86(6), 1647-1658. https://doi.org/10.1007/s00253-010-2538-y

81. Juturu, V., \& Wu, J. C. (2012). Microbial xylanases: Engineering, production and industrial applications. Biotechnology Advances, 30(6), 1219-1227. https://doi.org/10.1016/j.biotechadv.2011.11.006

82. Kameshwar, A. K. S., \& Qin, W. (2017). Qualitative and Quantitative Methods for Isolation and Characterization of Lignin-Modifying Enzymes Secreted by Microorganisms. Bioenergy Research, 10(1), 248-266. https://doi.org/10.1007/s12155016-9784-5

83. Karich, A., Ullrich, R., Scheibner, K., \& Hofrichter, M. (2017). Fungal unspecific peroxygenases oxidize the majority of organic EPA priority pollutants. Frontiers in Microbiology, 8(AUG). https://doi.org/10.3389/fmicb.2017.01463

84. Karigar, C. S., \& Rao, S. S. (2011). Role of microbial enzymes in the bioremediation of pollutants: A review. Enzyme Research, 2011(1). https://doi.org/10.4061/2011/805187

85. Karim, A., Nawaz, M. A., Aman, A., \& Ul Qader, S. A. (2015). Oxidoreductases on their way to industrial biotransformation. Journal of Radiation Research and Applied Sciences, 8(2), 160-165. https://doi.org/10.1016/j.jrras.2014.06.004

86. Karimi, K., \& Zamani, A. (2013). Mucor indicus: Biology and industrial application perspectives: A review. Biotechnology Advances, 31(4), 466-481. https://doi.org/10.1016/j.biotechadv.2013.01.009

87. Khambhaty, Y., Akshaya, R., Rama Suganya, C., Sreeram, K. J., \& Raghava Rao, J. (2018). A logical and sustainable approach towards bamboo pulp bleaching using xylanase from Aspergillus nidulans. International Journal of Biological Macromolecules, 118, 452-459. https://doi.org/10.1016/j.ijbiomac.2018.06.100

88. Khoury, G. A., Fazelinia, H., Chin, J. W., Pantazes, R. J., Cirino, P. C., \& Maranas, C. D. (2009). Computational design of Candida boidinii xylose reductase for altered cofactor specificity. Protein Science, 18(10), 2125-2138. https://doi.org/10.1002/pro.227

89. Kim, H., Padmakshan, D., Li, Y., Rencoret, J., Hatfield, R. D., \& Ralph, J. (2017). Characterization and Elimination of Undesirable Protein Residues in Plant Cell Wall 
International Journal of Agriculture and Environmental Research

ISSN: 2455-6939

Volume: 07, Issue: 01 "January-February 2021"

Materials for Enhancing Lignin Analysis by Solution-State Nuclear Magnetic Resonance Spectroscopy. Biomacromolecules, $\quad$ 18(12), 4184-4195. https://doi.org/10.1021/acs.biomac.7b01223

90. Kuhad, R. C., Deswal, D., Sharma, S., Bhattacharya, A., Jain, K. K., Kaur, A., Pletschke, B. I., Singh, A., \& Karp, M. (2016). Revisiting cellulase production and redefining current strategies based on major challenges. Renewable and Sustainable Energy Reviews, 55, 249-272. https://doi.org/10.1016/j.rser.2015.10.132

91. Kuhad, R. C., Gupta, R., \& Singh, A. (2011). Microbial cellulases and their industrial applications. Enzyme Research, 2011(1). https://doi.org/10.4061/2011/280696

92. Kumar, A., \& Chandra, R. (2020). Ligninolytic enzymes and its mechanisms for degradation of lignocellulosic waste in environment. Heliyon, 6(2), e03170. https://doi.org/10.1016/j.heliyon.2020.e03170

93. Kumar, P., Barrett, D. M., Delwiche, M. J., \& Stroeve, P. (2009). Methods for pretreatment of lignocellulosic biomass for efficient hydrolysis and biofuel production. Industrial and Engineering Chemistry Research, 48(8), 3713-3729. https://doi.org/10.1021/ie801542g

94. Lairson, L. L., Watts, A. G., Wakarchuk, W. W., \& Withers, S. G. (2006). Using substrate engineering to harness enzymatic promiscuity and expand biological catalysis. Nature Chemical Biology, 2(12), 724-728. https://doi.org/10.1038/nchembio828

95. Langston, J. A., Shaghasi, T. cellulose depolymerization by the enzymes cellobiose dehydrogenase and glycoside hydrolase 61, Abbate, E., Xu, F., Vlasenko, E., \& Sweeney, M. D. (2011). Oxidoreductive Cellulose Depolymerization by the Enzymes Cellobiose Dehydrogenase and Glycoside Hydrolase 61. Applied and Environmental Microbiology, 77(19), 7007-7015. https://doi.org/10.1128/AEM.05815-11

96. Laurent, C. V. F. P., Breslmayr, E., Tunega, D., Ludwig, R., \& Oostenbrink, C. (2019). Interaction between Cellobiose Dehydrogenase and Lytic Polysaccharide Monooxygenase [Research-article]. Biochemistry, 58(9), 1226-1235. https://doi.org/10.1021/acs.biochem.8b01178

97. Lee, S. S., Moon, D. S., Choi, H. T., \& Song, H. G. (2007). Purification and characterization of an intracellular NADH: Quinone reductase from Trametes versicolor. Journal of Microbiology, 45(4), 333-338.

98. Li, M., Zhou, Y., Ju, C., \& Fang, Y. (2016). Remarkable increasing of ZSM-5 lifetime in methanol to hydrocarbon reaction by post engineering in fluoride media. Applied Catalysis A: General, 512,1-8. https://doi.org/10.1016/j.apcata.2015.12.001

99. Li, Y., \& Cirino, P. C. (2014). Recent advances in engineering proteins for biocatalysis. Biotechnology and Bioengineering, 111(7), 1273-1287. https://doi.org/10.1002/bit.25240

100. Liers, C., Arnstadt, T., Ullrich, R., \& Hofrichter, M. (2011). Patterns of lignin 
International Journal of Agriculture and Environmental Research

ISSN: 2455-6939

Volume: 07, Issue: 01 "January-February 2021"

degradation and oxidative enzyme secretion by different wood- and litter-colonizing basidiomycetes and ascomycetes grown on beech-wood. FEMS Microbiology Ecology, 78(1), 91-102. https://doi.org/10.1111/j.1574-6941.2011.01144.x

101. Limaye, L., Patil, R., Ranadive, P., \& Kamath, G. (2017). Application of Potent Actinomycete Strains for Bio-Degradation of Domestic Agro-Waste by Composting and Treatment of Pulp-Paper Mill Effluent. Advances in Microbiology, 07(01), 94-108. https://doi.org/10.4236/aim.2017.71008

102. Linde, D., Ruiz-Dueñas, F. J., Fernández-Fueyo, E., Guallar, V., Hammel, K. E., Pogni, R., \& Martínez, A. T. (2015). Basidiomycete DyPs: Genomic diversity, structuralfunctional aspects, reaction mechanism and environmental significance. Archives of Biochemistry and Biophysics, 574, 66-74. https://doi.org/10.1016/j.abb.2015.01.018

103. Luo, L., Cai, J., Wang, C., Lin, J., Du, X., Zhou, A., \& Xiang, M. (2016). Purification and characterization of an alkaliphilic endo-xylanase from Streptomyces althioticus LMZM and utilization in the pulp paper industry. Journal of Chemical Technology and Biotechnology, 91(4), 1093-1098. https://doi.org/10.1002/jctb.4690

104. M., D., H., S., \& W., Q. (2009). Fungal bioconversion of lignocellulosic residues; opportunities \& perspectives. International Journal of Biological Sciences, 5(6), 578.

105. Manavalan, T., Manavalan, A., \& Heese, K. (2015). Characterization of Lignocellulolytic Enzymes from White-Rot Fungi. Current Microbiology, 70(4), 485-498. https://doi.org/10.1007/s00284-014-0743-0

106. Marcelo, E., Aplicaciones, E. Y., Despolimerización, M. D. E., \& La, P. (2013). Lignin, Structure and Applications Depolymerization Methods for Obtaining Aromatic Derivatives of Industrial Interest. In Avances en Ciencias e Ingeniería (Vol. 4, Issue 4).

107. Martínez, A. T., Ruiz-Dueñas, F. J., Camarero, S., Serrano, A., Linde, D., Lund, H., Vind, J., Tovborg, M., Herold-Majumdar, O. M., Hofrichter, M., Liers, C., Ullrich, R., Scheibner, K., Sannia, G., Piscitelli, A., Pezzella, C., Sener, M. E., Kılı̨̧, S., van Berkel, W. J. H., ... Alcalde, M. (2017). Oxidoreductases on their way to industrial biotransformations. Biotechnology Advances, 35(6), 815-831. https://doi.org/10.1016/j.biotechadv.2017.06.003

108. Martínez, Á. T., Ruiz-Dueñas, F. J., Martínez, M. J., del Río, J. C., \& Gutiérrez, A. (2009). Enzymatic delignification of plant cell wall: from nature to mill. Current Opinion in Biotechnology, 20(3), 348-357. https://doi.org/10.1016/j.copbio.2009.05.002

109. Martínez, Á. T., Speranza, M., Ruiz-Dueñas, F. J., Ferreira, P., Camarero, S., Guillén, F., Martínez, M. J., Gutiérrez, A., \& Del Río, J. C. (2005). Biodegradation of lignocellulosics: Microbial, chemical, and enzymatic aspects of the fungal attack of lignin. International Microbiology, 8(3), 195-204. https://doi.org/10.2436/im.v8i3.9526

110. Mate, D. M., \& Alcalde, M. (2017). Laccase: a multi-purpose biocatalyst at the forefront 
International Journal of Agriculture and Environmental Research

ISSN: 2455-6939

Volume: 07, Issue: 01 "January-February 2021"

of biotechnology. Microbial Biotechnology, 10(6), 1457-1467. https://doi.org/10.1111/1751-7915.12422

111. Matsagar, B. M., \& Dhepe, P. L. (2017). Effects of cations, anions and H+ concentration of acidic ionic liquids on the valorization of polysaccharides into furfural. New Journal of Chemistry, 41(14), 6137-6144. https://doi.org/10.1039/c7nj00342k

112. Mattila, H., Kuuskeri, J., \& Lundell, T. (2017). Single-step, single-organism bioethanol production and bioconversion of lignocellulose waste materials by phlebioid fungal $\begin{array}{llll}\text { species. } & \text { Bioresource } & \text { Technology, } & 225,\end{array}$ https://doi.org/10.1016/j.biortech.2016.11.082

113. McPhillips, K., Waters, D. M., Parlet, C., Walsh, D. J., Arendt, E. K., \& Murray, P. G. (2014). Purification and characterisation of a $\beta-1,4-x y l a n a s e$ from Remersonia thermophila CBS 540.69 and its application in bread making. Applied Biochemistry and Biotechnology, 172(4), 1747-1762. https://doi.org/10.1007/s12010-013-0640-1

114. Mikolasch, A., \& Schauer, F. (2009). Fungal laccases as tools for the synthesis of new hybrid molecules and biomaterials. Applied Microbiology and Biotechnology, 82(4), 605-624. https://doi.org/10.1007/s00253-009-1869-z

115. Millati, R., Syamsiah, S., Niklasson, C., Nur Cahyanto, M., Lundquist, K., \& Taherzadeh, M. J. (2011). Biological pretreatment: Review. BioResources, 6(4), 5224-5259.

116. Mohan, S. V., Butti, S. K., Amulya, K., Dahiya, S., \& Modestra, J. A. (2016). Waste Biorefinery: A New Paradigm for a Sustainable Bioelectro Economy. Trends in Biotechnology, 34(11), 852-855. https://doi.org/10.1016/j.tibtech.2016.06.006

117. Molina, G., Contesini, F. J., Melo, R. R. De, Sato, H. H., \& Pastore, G. M. (2016). $\beta$ Glucosidase From Aspergillus. In New and Future Developments in Microbial Biotechnology and Bioengineering. Elsevier B.V. https://doi.org/10.1016/B978-0-44463505-1.00011-7

118. Motta, F. L., Andrade, C. C. P., \& Santana, M. H. A. (2015). A Review of Xylanase Production by the Fermentation of Xylan: Classification, Characterization and Applications. Sustainable Degradation of Lignocellulosic Biomass - Techniques, Applications and Commercialization.

119. Naidu, D. S., Hlangothi, S. P., \& John, M. J. (2018). Bio-based products from xylan: A review. Carbohydrate Polymers, 179(September 2017), 28-41. https://doi.org/10.1016/j.carbpol.2017.09.064

120. Naraian, R., \& Gautam, R. L. (2017). Penicillium enzymes for the saccharification of lignocellulosic feedstocks. In New and Future Developments in Microbial Biotechnology and Bioengineering: Penicillium System Properties and Applications. Elsevier B.V. https://doi.org/10.1016/B978-0-444-63501-3.00006-5

121. Nieves, D. C., Karimi, K., \& Horváth, I. S. (2011). Improvement of biogas production 
International Journal of Agriculture and Environmental Research

ISSN: 2455-6939

Volume: 07, Issue: 01 "January-February 2021"

from oil palm empty fruit bunches (OPEFB). Industrial Crops and Products, 34(1), 1097-1101. https://doi.org/10.1016/j.indcrop.2011.03.022

122. Nieves, D. C., Ruiz, H. A., de Cárdenas, L. Z., Alvarez, G. M., Aguilar, C. N., Ilyina, A., \& Martínez Hernández, J. L. (2016). Enzymatic hydrolysis of chemically pretreated mango stem bark residues at high solid loading. Industrial Crops and Products, 83, 500508. https://doi.org/10.1016/j.indcrop.2015.12.079

123. Niño-Medina, G., Gutiérrez-Soto, G., Urías-Orona, V., Hernández-Luna, C. E., \& Yildiz, F. (2017). Effect of laccase from Trametes maxima CU1 on physicochemical quality of bread . Cogent Food \& Agriculture, 3(1), 1328762. https://doi.org/10.1080/23311932.2017.1328762

124. Niu, C., Zhu, L., Xu, X., \& Li, Q. (2016). Rational design of disulfide bonds increases thermostability of a mesophilic 1,3-1,4- $\beta$-glucanase from Bacillus terquilensis. PLoS ONE, 11(4). https://doi.org/10.1371/journal.pone.0154036

125. Nunes, C. S. (2018). General perspectives of enzymes, environment preservation, and scarce natural resources-conclusions. In Enzymes in Human and Animal Nutrition: Principles and Perspectives. Elsevier Inc. https://doi.org/10.1016/B978-0-12-8054192.00027-7

126. Parra-Saldivar, R., Ramirez-Mendoza, R. A., Sharma, A., Oza, G., Zavala-Yoe, R., \& Iqbal, H. M. N. (2020). Robust enzymes designing for efficient biocatalysis. In Biomass, Biofuels, Biochemicals. BV. https://doi.org/10.1016/b978-0-12-819820-9.00004-1

127. Pathak, P., Bhardwaj, N. K., \& Singh, A. K. (2014). Production of crude cellulase and xylanase from Trichoderma harzianum PPDDN10 NFCCI-2925 and its application in photocopier waste paper recycling. Applied Biochemistry and Biotechnology, 172(8), 3776-3797. https://doi.org/10.1007/s12010-014-0758-9

128. Paz, A., Costa-Trigo, I., Oliveira, R. P. de S., \& Domínguez, J. M. (2020). Ligninolytic Enzymes of Endospore-Forming Bacillus aryabhattai BA03. Current Microbiology, 77(5), 702-709. https://doi.org/10.1007/s00284-019-01856-9

129. Penttilä, P. A., Várnai, A., Pere, J., Tammelin, T., Salmén, L., Siika-aho, M., Viikari, L., \& Serimaa, R. (2013). Xylan as limiting factor in enzymatic hydrolysis of nanocellulose. Bioresource Technology, 129, 135-141. https://doi.org/10.1016/j.biortech.2012.11.017

130. Phitsuwan, P., Laohakunjit, N., Kerdchoechuen, O., Kyu, K. L., \& Ratanakhanokchai, K. (2013). Present and potential applications of cellulases in agriculture, biotechnology, and bioenergy. Folia Microbiologica, 58(2), 163-176. https://doi.org/10.1007/s12223-0120184-8

131. Plácido, J., \& Capareda, S. (2015). Ligninolytic enzymes: A biotechnological alternative for bioethanol production. Bioresources and Bioprocessing, 2(1). https://doi.org/10.1186/s40643-015-0049-5 
International Journal of Agriculture and Environmental Research

ISSN: 2455-6939

Volume: 07, Issue: 01 "January-February 2021"

132. Poletto, M., Ornaghi Júnior, H. L., \& Zattera, A. J. (2014). Native cellulose: Structure, characterization and thermal properties. Materials, 7(9), 6105-6119. https://doi.org/10.3390/ma7096105

133. Polizeli, M. L. T. M., Rizzatti, A. C. S., Monti, R., Terenzi, H. F., Jorge, J. A., \& Amorim, D. S. (2005). Xylanases from fungi: Properties and industrial applications. Applied Microbiology and Biotechnology, 67(5), 577-591. https://doi.org/10.1007/s00253-005-1904-7

134. Ramírez-Cavazos, L. I., Junghanns, C., Ornelas-Soto, N., Cárdenas-Chávez, D. L., Hernández-Luna, C., Demarche, P., Enaud, E., García-Morales, R., Agathos, S. N., \& Parra, R. (2014). Purification and characterization of two thermostable laccases from Pycnoporus sanguineus and potential role in degradation of endocrine disrupting chemicals. Journal of Molecular Catalysis B: Enzymatic, 108, 32-42. https://doi.org/10.1016/j.molcatb.2014.06.006

135. Rodríguez-Delgado, M. M., Alemán-Nava, G. S., Rodríguez-Delgado, J. M., DieckAssad, G., Martínez-Chapa, S. O., Barceló, D., \& Parra, R. (2015). Laccase-based biosensors for detection of phenolic compounds. TrAC - Trends in Analytical Chemistry, 74, 21-45. https://doi.org/10.1016/j.trac.2015.05.008

136. Rodríguez-Delgado, M., Orona-Navar, C., García-Morales, R., Hernandez-Luna, C., Parra, R., Mahlknecht, J., \& Ornelas-Soto, N. (2016). Biotransformation kinetics of pharmaceutical and industrial micropollutants in groundwaters by a laccase cocktail from Pycnoporus sanguineus CS43 fungi. International Biodeterioration and Biodegradation, 108, 34-41. https://doi.org/10.1016/j.ibiod.2015.12.003

137. Rodríguez Couto, S., \& Toca Herrera, J. L. (2006). Industrial and biotechnological applications of laccases: A review. Biotechnology Advances, 24(5), 500-513. https://doi.org/10.1016/j.biotechadv.2006.04.003

138. Saini, A., Aggarwal, N. K., Sharma, A., \& Yadav, A. (2015). Prospects for Irradiation in Cellulosic Ethanol Production. Biotechnology Research International, 2015, 1-13. https://doi.org/10.1155/2015/157139

139. Salazar-López, M., Rostro-Alanis, M. J., Castillo-Zacarías, C., Parra-Guardado, A. L., Hernández-Luna, C., Iqbal, H. M. N., \& Parra-Saldivar, R. (2017). Induced Degradation of Anthraquinone-Based Dye by Laccase Produced from Pycnoporus sanguineus (CS43). Water, Air, and Soil Pollution, 228(12). https://doi.org/10.1007/s11270-017-3644-6

140. Santos, A., Mendes, S., Brissos, V., \& Martins, L. O. (2014). New dye-decolorizing peroxidases from Bacillus subtilis and Pseudomonas putida MET94: Towards biotechnological applications. Applied Microbiology and Biotechnology, 98(5), 20532065. https://doi.org/10.1007/s00253-013-5041-4

141. Sarrouh, B. (2012). Up-To-Date Insight on Industrial Enzymes Applications and Global 
International Journal of Agriculture and Environmental Research

ISSN: 2455-6939

Volume: 07, Issue: 01 "January-February 2021"

Market. Journal of Bioprocessing \& Biotechniques, sl(01). https://doi.org/10.4172/21559821.s4-002

142. Shah, F., Ranawat, B., \& Mishra, S. (2019). An approach toward cellulase production, bioconversion, and utilization. In Advanced Bioprocessing for Alternative Fuels, Biobased Chemicals, and Bioproducts: Technologies and Approaches for Scale-Up and Commercialization. Elsevier Inc. https://doi.org/10.1016/B978-0-12-817941-3.00011-5

143. Shirkavand, E., Baroutian, S., Gapes, D. J., \& Young, B. R. (2016). Combination of fungal and physicochemical processes for lignocellulosic biomass pretreatment - A review. Renewable and Sustainable Energy Reviews, 54, 217-234. https://doi.org/10.1016/j.rser.2015.10.003

144. Singh, R., Kumar, M., Mittal, A., \& Mehta, P. K. (2016). Microbial enzymes: industrial progress in 21st century. 3 Biotech, 6(2). https://doi.org/10.1007/s13205-016-0485-8

145. Srivastava, S., Dafale, N. A., Tulsani, N., Jakhesara, S. J., Patil, N. V., Joshi, C. G., \& Purohit, H. J. (2021). Evaluation of designed consortium SNH-1 for efficient hydrolysis of agriculture waste to benefit bioethanol production. Journal of Cleaner Production, 288. https://doi.org/10.1016/j.jclepro.2020.125601

146. Suárez Arango, C., \& Nieto, I. J. (2013). Cultivo biotecnológico de macrohongos comestibles: Una alternativa en la obtención de nutracéuticos. Revista Iberoamericana de Micologia, 30(1), 1-8. https://doi.org/10.1016/j.riam.2012.03.011

147. Sulej, J., Osińska-Jaroszuk, M., Jaszek, M., Grąz, M., Kutkowska, J., Pawlik, A., Chudzik, A., \& Bancerz, R. (2019). Antimicrobial and antioxidative potential of free and immobilised cellobiose dehydrogenase isolated from wood degrading fungi. Fungal Biology, 123(12), 875-886. https://doi.org/10.1016/j.funbio.2019.09.007

148. Sun, Y. C., Wen, J. L., Xu, F., \& Sun, R. C. (2011). Structural and thermal characterization of hemicelluloses isolated by organic solvents and alkaline solutions from Tamarix austromongolica. Bioresource Technology, 102(10), 5947-5951. https://doi.org/10.1016/j.biortech.2011.03.012

149. Teerapatsakul, C., Parra, R., Keshavarz, T., \& Chitradon, L. (2017). Repeated batch for dye degradation in an airlift bioreactor by laccase entrapped in copper alginate. International Biodeterioration and Biodegradation, 120, 52-57. https://doi.org/10.1016/j.ibiod.2017.02.001

150. Tenhunen, T. M., Peresin, M. S., Penttilä, P. A., Pere, J., Serimaa, R., \& Tammelin, T. (2014). Significance of xylan on the stability and water interactions of cellulosic nanofibrils. Reactive and Functional Polymers, 85, 157-166. https://doi.org/10.1016/j.reactfunctpolym.2014.08.011

151. Tinoco, R., Verdin, J., \& Vazquez-Duhalt, R. (2007). Role of oxidizing mediators and tryptophan 172 in the decoloration of industrial dyes by the versatile peroxidase from 
International Journal of Agriculture and Environmental Research

ISSN: 2455-6939

Volume: 07, Issue: 01 "January-February 2021"

Bjerkandera adusta. Journal of Molecular Catalysis B: Enzymatic, 46(1-4), 1-7. https://doi.org/10.1016/j.molcatb.2007.01.006

152. Toor, M., Kumar, S. S., Malyan, S. K., Bishnoi, N. R., Mathimani, T., Rajendran, K., \& Pugazhendhi, A. (2020). An overview on bioethanol production from lignocellulosic feedstocks. $\quad$ Chemosphere, 125080. https://doi.org/10.1016/j.chemosphere.2019.125080

153. Toushik, S. H., Lee, K. T., Lee, J. S., \& Kim, K. S. (2017). Functional Applications of Lignocellulolytic Enzymes in the Fruit and Vegetable Processing Industries. Journal of Food Science, 82(3), 585-593. https://doi.org/10.1111/1750-3841.13636

154. Tovar Herrera, O. E. (2013). Evaluación De Un Material Lignocelulósico Para La Producción De Celulasas, Xilanasas Y Lacasas Por Basidiomicetos Del Noreste De Mexico. Universidad Autónoma de Nuevo León: Facultad de Ciencias Biológicas, April. https://doi.org/10.13140/RG.2.1.3322.8324

155. Ussiri, D. A. N., \& Lal, R. (2014). Miscanthus agronomy and bioenergy feedstock potential on minesoils. Biofuels, 5(6), 741-770. https://doi.org/10.1080/17597269.2015.1024388

156. Vazquez-Ortega, P. G., Alcaraz-Fructuoso, M. T., Rojas-Contreras, J. A., LópezMiranda, J., \& Fernandez-Lafuente, R. (2018). Stabilization of dimeric $\beta$-glucosidase from Aspergillus niger via glutaraldehyde immobilization under different conditions. Enzyme and Microbial Technology, 110(December 2017), 38-45. https://doi.org/10.1016/j.enzmictec.2017.12.007

157. Wang, X., Pei, D., Teng, Y., \& Liang, J. (2018). Effects of enzymes to improve sensory quality of frozen dough bread and analysis on its mechanism. Journal of Food Science and Technology, 55(1), 389-398. https://doi.org/10.1007/s13197-017-2950-8

158. Winquist, E., Moilanen, U., Mettälä, A., Leisola, M., \& Hatakka, A. (2008). Production of lignin modifying enzymes on industrial waste material by solid-state cultivation of fungi. Biochemical Engineering Journal, 42(2), 128-132. https://doi.org/10.1016/j.bej.2008.06.006

159. Yang, D. D., François, J. M., \& de Billerbeck, G. M. (2012). Cloning, expression and characterization of an aryl-alcohol dehydrogenase from the white-rot fungus Phanerochaete chrysosporium strain BKM-F-1767. BMC Microbiology, 12. https://doi.org/10.1186/1471-2180-12-126

160. Yao, G., Wu, R., Kan, Q., Gao, L., Liu, M., Yang, P., Du, J., Li, Z., \& Qu, Y. (2016). Production of a high-efficiency cellulase complex via B-glucosidase engineering in Penicillium oxalicum. Biotechnology for Biofuels, 9(1), 1-11. https://doi.org/10.1186/s13068-016-0491-4

161. Yin, Q., Zhou, G., Peng, C., Zhang, Y., Kües, U., Liu, J., Xiao, Y., \& Fang, Z. (2019). 
The first fungal laccase with an alkaline $\mathrm{pH}$ optimum obtained by directed evolution and its application in indigo dye decolorization. AMB Express, 9(1), 1-13. https://doi.org/10.1186/s13568-019-0878-2

162. Zhang, M., Wan, Y., Wen, Y., Li, C., \& Kanwal, A. (2020). A novel Poly(vinyl alcohol) / carboxymethyl cellulose / yeast double degradable hydrogel with yeast foaming and double degradable property. Ecotoxicology and Environmental Safety, 187(September 2019), 109765. https://doi.org/10.1016/j.ecoenv.2019.109765

163. Zhang, X., Li, J., Yang, W., \& Blasiak, W. (2011). Formation mechanism of levoglucosan and formaldehyde during cellulose pyrolysis. Energy and Fuels, 25(8), 3739-3746. https://doi.org/10.1021/ef2005139

164. Zhao, X., Xiong, L., Zhang, M., \& Bai, F. (2016). Towards efficient bioethanol production from agricultural and forestry residues: Exploration of unique natural microorganisms in combination with advanced strain engineering. Bioresource Technology, 215, 84-91. https://doi.org/10.1016/j.biortech.2016.03.158 